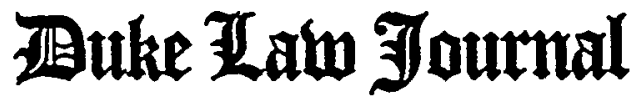

VOLUME 1971

August

NUMBER 3

\section{CONSTITUTIONAL LAW REFORM FOR THE POOR: BODDIE v. CONNECTICUT}

\author{
ARTHUR B. LAFRANCE*
}

Providing legal counsel to the poor has become a matter of considerable complexity and difficulty, requiring expertise comparable to that in other areas of the law. Perhaps this is not a surprising proposition; indeed, it should not be. Yet the assumption often seems to have been that any lawyer could represent the poor. Certainly this was the premise of the volunteer legal aid programs of bar associations preceding federal involvement in poverty law. Too, in recent Judicare proposals ${ }^{1}$ there is implicit the assumption that poverty clients can be indiscriminately distributed to members of the practicing bar, possibly because the routine impositions of society upon the poor are customarily assumed not to be amenable to legal redress. For years lawyers have despaired of doing more than "bandaid" work for the poor-reducing wage executions, getting a month's extension before a tenant would be forced to vacate, arranging for a private charity to fill the gap left when welfare benefits were terminated. Such services were useful, but they had little lasting

* Professor of Law, Arizona State University. B.A. 1960, Dartmouth College; LL.B. 1963, Yale University. The author was counsel for the appellants in Boddie v. Connecticut, 401 U.S. 371 (1971), the principal case discussed in this article.

1. Judicare is a method of delivering legal services to the poor by assigning cases to members of the local bar, in contrast to the fultime, neighborhood office approach of the Office of Economic Opportunity. The author of this article administered a model Judicare office during 1968 in New Haven, Connecticut. His experience indicates that panels of private attorneys are more expensive, less expert and less enthusiastic than fulltime staff attorneys in serving the poor. As to the dispute concerning Judicare and its merits, see In re Community Legal Servs. Inc., 43 Pa. D. \& C.2d 51 (Phila. County Ct. 1967); Marsh, Neighborhood Law Offices or Judicare? 25 LEg. AID BRIeF \& CASE 12 (1960); Preloznik, Wisconsin Judicare, 70 W. VA. L. Rev. 326 (1968); Robb, Alternate Legal Assistance Plans, 14 CATH. LAw. 127 (1968); Samore, Legal Services for the Poor, 32 ALB. L. REv. 509 (1968); Schlossberg \& Weinberg, The Role of Judicare in the American Legal System, 54 A.B.A.J. 1000 (1968). 
impact on the law or society. ${ }^{2}$ The attorneys' talents were not challenged by the routine grist of the poor.

Yet that routine grist has always been amenable to imaginative analysis. Wage executions need not always be compromised; a lawyer might pause to consider that the execution because of its very value to a creditor-inordinate pressure upon a marginal wage earner-may deny due process. ${ }^{3} \mathrm{~A}$ welfare recipient need not struggle for weeks or months without benefits before being told why they have been terminated; a lawyer might argue that deprivation prior to a hearing constitutes a denial of due process. ${ }^{4}$ Tenants seeking sanitary or healthful conditions under housing laws need not be subject to eviction for filing complaints; a lawyer might conclude the first amendment protects such activities. ${ }^{5}$ And substandard housing may violate not only the law but also implied conditions of a lease, if a covenant of habitability can be inferred from comprehensive housing codes. ${ }^{6}$

Unconventional analysis by an attorney may, as in the instances cited above, transform a routine frustration into an opportunity for significant legal service to the poor. But this requires special skills and innovative legal tools. This article will discuss how one such

2. Support for these and other comments in this article concerning legal services programs may be found in the following: P. WALD, LAW AND POVERTY: 1965 A REPORT TO THE National Conference on Law and Poverty (1965); National Conference on LaW and Poverty, Conference Proceedings (1965); Cahn \& Cahn, What Price Justice: The Civilian Perspective Revisited, 41 Notre Dame Law. 927 (1966); Cahn \& Cahn, The War on Poverty:A Civilian Perspective, 73 YALE L.J. 1317 (1964); Carlin \& Howard, Legal Representation and Class Justice, 12 U.C.L.A.L. REv. 381 (1965); Cheatham, A Lawyer When Needed: Legal Services for the Middle Classes, 63 Coivum. L. REv. 973 (1963); Cheatham, A vailability of Legal Services: The Responsibility of the Individual Lawyer and of the Organized Bar, 12 U.C.L.A. L. REv. 438 (1965); Frankel, Experiments in Serving the Indigent, 51 A.B.A.J. 460 (1965); McCalpin, The Bar Faces Forward, 51 A.B.A.J. 548 (1965); Paulsen, The Expanding Horizon of Legal Services, 67 W. VA. L. REv. 179, (1965); Pye, The Role of Legal Services in the Antipoverty Program, 31 LAw \& Contemp. Prob. 211 (1966); Pye \& Garraty, The Involvement of the Bar in the War Against Poverty, 41 Notre Dame Law. 860 (1966); Schein, Legal Aid Utopia, 33 J.B.A.D.C. 16 (1966); Shapo, "Thou Shalt Not Ration Justice": The Law and the Poor Man in the Sixties, 55 CoRnel. L. Rev. 44 (1969); Silver, The Imminent Failure of Legal Services for the Poor: Why and How to Limit Caseload, 46 J. URB. LAw 217 (1969); Sparer, The Role of the Welfare Client's Lawyer, 12 U.C.L.A.L. REV. 361 (1965); Comment, Neighborhood Law Offices: The New Wave in Legal Services for the Poor, 80 HARv. L. REV. 805 (1967).

3. See Sniadach v. Family Fin. Corp., 395 U.S. 337 (1969).

4. See Goldberg v. Kelly, 397 U.S. 254 (1970).

5. See Hosey v. Club Van Cortlandt, 299 F. Supp. 501 (S.D.N.Y. 1969).

6. See Javins v. First Nat'l Realty Corp., 428 F.2d 1071 (D.C. Cir. 1970). 
innovative approach, using federal civil rights legislation on behaif of the poor, dealt with a seemingly routine matter-the barring of the poor from the courts because of inability to pay filing fees and service of process.

The case involved is Boddie $v$. Connecticut, ${ }^{7}$ decided by the United States Supreme Court on March 2, 1971. The appellants, all female welfare recipients, sought divorces in the courts of Connecticut, which would not waive filing fees or arrange service of process. The expenses, totaling approximately sixty dollars, effectively barred the appellants from the courts. Suit was brought in the United States District Court for the District of Connecticut, claiming denial of equal protection and due process as guaranteed by the fourteenth a mendment to the United States Constitution. That court denied relief, ${ }^{8}$ but was reversed on direct appeal by the Supreme Court.

The rationale of Justice Harlan's majority opinion, emphasizing narrow due process grounds, has significant implications. The decision in Boddie points irresistably toward other areas of the law-procedural matters in addition to costs, substantive matters in addition to divorce, and state-imposed fees beyond the court system. On a more theoretical plane, the decision sheds further light on the confusing relationship between the guarantees of due process, equal protection and the Bill of Rights. ${ }^{9}$ All of this takes on added significance when considered against the background of the position appellants had urged upon the Court.

The importance of Boddie lies not only in what the Supreme Court did but also in how the case was selected, shaped and presented. Boddie involved a routine matter for poverty lawyers-filing fees as a barrier to clients-but was resolved in a most un-routine fashion. How and why should be of significance for future hitigation on behalf of the poor.

Too, Boddie involved not merely representing poor clients, but doing so for law reform purposes. This, of necessity, implies a sense of priorities in choosing which of many cases should be brought and in

7. 401 U.S. 371 (1971). See generally Cohen, Divorce Filing Fees in Indian Tribal Courts: A First Look After Boddie v. Connecticul, 1970 L. \& SOC. ORDER 541.

8. Boddie v. Connecticut, 286 F. Supp. 968 (D. Conn. 1968).

9. The volume of literature on this confluence of constitutional doctrine is staggering. A beginning reference might be W. LOCKHART, Y. Kamisar \& J. ChOPER, CONSTITUTIONAL LAW $441-537,590-609,1176-1363$ (3d ed. 1970). This provides an extremely useful introduction to the literature, cases and cross-currents in this area. 
allocating scant manpower resources. ${ }^{10}$ There are many problems in law reform for the poor, some of which were involved in Boddie and will be discussed below.

Thus this article will have a two-fold focus: on Boddie as typifying law reform-poverty litigation and on Boddie as a significant decision by the United States Supreme Court.

\section{Legal Services, The Poor and Court Costs}

There are approximately 270 legal services programs serving the poor in the United States. Most have come into existence since 1966, at which time federal funding became available under the Economic Opportunity Act. ${ }^{11}$ All are predicated on the assumption that access to the courts is a fundamental value of our society. This, it may be assumed, is because of the value of courts as an alternative to more direct means of resolving disputes; ${ }^{12}$ self-help is often little more than an invitation to violence. ${ }^{13}$ The central mission of legal services, then, was to bring together the courts and the poor.

The courts have always promised equal justice, ${ }^{14}$ but it is a truism that the promise fell far short of reality. Substantive laws frequently favor the moneyed, commercial interests of society, and the processes

10. The problems posed by lack of experienced attorneys, overwhelming caseloads and the need to allocate resources have been crucial for OEO-funded legal services programs since the outset and remain so today. See note 2 supra.

11. 42 U.S.C. $\S 2809$ (Supp. V. 1970).

12. In Boddie, this central role of the courts was emphasized by Justice Harlan's majority opinion. 401 U.S. at 375 . As long ago as 1907 the Supreme Court said:

The right to sue and defend in the courts is the alternative of force. In an organized society it is the right conservative of all other rights, and lies at the foundation of orderly government. It is one of the highest and most essential privileges of citizenship . . . . Chambers v. Baltimore \& O. R.R., 207 U.S. 142, 148 (1907).

13. See, for example, Wheeler v. Thompson, CCH Pov. L. Rep. I 10,725 (D.C. Ct. Gen. Sess. 1969), limiting Snitman v. Goodman, 118 A.2d 394 (D.C. Mun. Ct. App. 1955) and holding that a self-help eviction is contrary to the public policy of the District of Columbia because

[f]irst, whenever there is resort to self help, violence and strife are close at hand. In this case, but a single assault occurred . . . . Any widespread use of self help by landlords in densely-settled urban areas is likely to have much more serious and lasting consequences .... CCH Pov. L. REP. II 10,725, at 11,586.

14. "Providing equal justice for poor and rich, weak and powerful alike is an age-old problem. People have never ceased to hope and strive to move closer to that goal." Griffin v. Illinois, 351 U.S. 12, 16 (1956). While the truth of this quotation may be admitted, Anatole France's ironic observation remains equally true, that "The law, in its majestic equality, forbids the rich as well as the poor to sleep under bridges, to beg in the streets, and to steal bread." 
of justice reflect a similar bias. ${ }^{15}$ Court costs range from a few dollars to several hundred, if the expense of service by publication is included. ${ }^{16}$ The poor by definition lack such resources. ${ }^{17}$ Roughly half of the states do not have provisions for waiving costs, thereby effectively denying the poor access to court. The legal services reform movement was thus frustrated at the threshold of its mission.

It has been said elsewhere, and hardly need be repeated here, that the riotous estrangement of ghetto dwellers from mainstream America can be attributed at least in part to their alienation from law and its processes. ${ }^{18}$ The problem has been recognized in the criminal area, and the expenses of criminal defense have been largely lifted

15. See, e.g., J. Carlin, J. Howard \& S. Messinger, Civil Justice and the Poor (1967) (as to civil laws and procedure); National Advisory Commission on Civil Disorders, Report of the National advisory Commission on Civil Disorders (The Kerner COMMISSION REPORT) (1968) (as to criminal law and process). For a more specific example of dual standards, see tenBroek, California's Dual System of Family Law: Its Origin, Development, and Present Status, 17 STAN. L. REv. 614 (1965). The bias of the court system against the poor often takes an ethnic turn. The cases dealing with poor Blacks in the South are legion. As to Mexican Americans, see United States Commission on Civil Rights, Mexican AMERicans aNd THe AdMinistration of JUSTice IN the Southwest (1970). Further amplification of this point seems hardly necessary; the fact that the federal government is investing some sixty million dollars annually in legal services for the poor is evidence of the inadequacy of the legal system, but the need is still not being met; see notes 55, 127-34 infra and accompanying text.

16. As to court costs and state waiver provisions prior to Boddie, ses Silverstein, Waiver of Court Costs and Appointment of Counsel for Poor Persons in Civil Cases, 2 VAlP. L. Rev. 21 (1967); Silverstein, Eligibility for Free Legal Services in Civil Cases, 44 J. URBAN LAW 549 (1967). The information provided by these studies was supplemented in a brief filed in Boddie by the National Legal Aid and Defender Association, surveying state in forma pauperis procedures, Brief for National Legal Aid and Defender Association as Amicus Curiae, Boddie v. Connecticut, 401 U.S. 371 (1971), and by affidavits filed with the Supreme Court following reargument. See notes 127-34 infra and accompanying text.

17. Various studies establish that court costs are particularly effective in deterring the poor from seeking divorces. See, e.g., R Cavan, The American Family 431-32 (3d ed. 1963); $\mathrm{w}$. GOODE, AFTER DivorCE 44, 51, 230-31 (1956); Lutz, Marital Incompatibility, in SOcIAL WORK and Social Problems 41 (N. Cohen ed. 1964); Rose, Race and Ethnic Relations, in Contemporary Social Problems 409, 418-34, $441-56$ (R. Merton \& R. Nisbet eds., 2d ed. 1966); Johnson, Suppressed, Delayed, Damaging and Avoided Divorces, 18 LAW \& CoNTEMP. Proв. 72 (1953); Mercer, Interrelations Among Family Stability, Family Composition, Residence, and Race, 29 J. MARRIAGe \& Family 456 (1967); Weeks, Differential Divorce Rates by Occupations, 21 Soc. ForCEs 334 (1943). As these and other authorities establish, access to divorce is at least in part a function of income. It hardly nceds saying that other factors influence divorce rates as well, including social class, race and religion. See note 57 infra.

18. See D. Caplovitz, The Poor Pay More 155-67 (1967); The Kerner Commission REPORT, supra note 15, at 292-93. See also note 15 supra. Conot, in his account of the 1965 Watts riot, makes numerous references to the legal system's maltreatment of the poor as affecting their views of society. R. CoNot, Rivers of Blood, YeArs OF DARKNesS (1967). 
from poor defendants, although this is a relatively recent development. It has only been since the 1955 decision of Griffin $v$. Illinois ${ }^{19}$ that the Constitutional imperative has been that the kind of trial a man gets cannot depend upon his purse. In the 1960's the implications of Griffin have been applied to counsel, ${ }^{20}$ appeals, ${ }^{21}$ and other facets of the criminal process. ${ }^{22}$

The courts were slow, however, in recognizing the same concepts in the civil area. Until the mid 1960 's scant attention was given to the subject of civil in forma pauperis litigation in the legal literature..$^{23} \mathrm{By}$ then the crisis was at hand. Across the nation, legal services programs in major cities were turning away hundreds of applicants too poor to pay filing fees. Thus, solving the problems posed by fees was crucial to success or failure of legal service programs.

A solution might be found in the courts if an appropriate test case could be shaped and presented. But test case litigation, particularly for the poor, is an endeavor often marked more by frustration than success.

\section{Selecting a Test Case}

Test case litigation, as a means of reform, is hardly a self-defining category. Some argue that appropriate test cases are those which stretch old concepts; others focus on the possible impact in numbers beyond the immediate litigants; still others look for change in processes and institutions. ${ }^{2 t}$ These criteria, while useful, are hardly

19. 351 U.S. 12 (1956).

20. Gideon v. Wainwright, 372 U.S. 335 (1963) (relating directly to the sixth amendment guarantee of counsel).

21. Burns v. Ohio, 360 U.S. 252 (1959).

22. Most recently, the Supreme Court has held that an indigent cannot be imprisoned for inability to pay a fine. Tate v. Short, 401 U.S. 395 (1971).

23. Prior to 1960 , the best article on equal protection of the laws was Tussman \& tenBroek, The Equal Protection of the Laws, 37 CALIF. L. Rev. 341 (1949). The position of the poor with respect to court proceedings began receiving attention in the mid 1960's. See generally CONFERENCE ON tHE LAW OF THE POOR (J. tenBroek ed. 1966); Willging, Financial Barriers and the Access of Indigents to the Courts, 57 Geo. L. J. 253 (1968); Note, The Right to Civil Counsel, 66 Colum. L. Rev. 1322 (1966); Note, Litigation Costs: The Hidden Barrier to the Indigent, 56 GEo. L.J. 516 (1968); Developments in the Law-Equal Protection, 82 HaRV. L. REv. 1065 (1969); Note, Discriminations Against the Poor and the Fourteenth Amendment, 81 HARv. L. Rev. 435 (1967); Nole, The Indigent's Right to Counsel in Civil Cases, 76 YaLE L.J. 545 (1967). See note 2 supra.

24. See generally note 2 supra. The debate as to what is sound law reform or, indeed, whether there can be such a concept has raged since the very beginning of OEO-funded legal services programs. See, e.g., Christensen, Give Us Don Baker Again, 4 Clearunghouse Rev. 51 (1971). As is apparent from the text of this article, the author is of the opinion that law reform 
precise or even mutually exclusive. And, there are those who challenge the basic notion of law reform itself, ${ }^{25}$ maintaining that routine services are the highest priority of the poor and, therefore, of legal services programs. While this position may have merit, the present inquiry is more limited, concerned with how-not why-to conduct law reform successfully.

Successful law reform necessarily includes winning. The danger of losing is increased in proportion to the distance between established precedent and the position asserted. Perhaps this is self evident, but an innate sense of justice is not enough to win a case; there must be a supporting background or context of positive law and decisional principles. To win, a litigant must begin where others have left off.

For example, welfare residency laws could be effectively challenged in $1968^{26}$ because previous decisions had begun to shape a constitutional right to travel and to impose a heavy burden of proof on states which discriminated in such a fashion as to impair constitutional rights. In contrast, welfare maximum grant legislation was prematurely challenged in $1969^{27}$ in part because the possible rights affected, such as family association and procreation, are in a primitive state of development, as is the emerging right to assert against the state an affirmative, constitutional duty of support.2s While a second challenge to welfare maxima may be successful at a later time, unfortunately, the unfavorable law generated by the previous, unsuccessful effort will hamper later challenges.

It is of course easy to say that one must wait for an idea's time to come; the progression from Dred Scott ${ }^{29}$ to Plessy v. Ferguson ${ }^{30}$ to

through test case litigation for the poor is not only possible but desirable. As to OEO's commitment to law reform, see CCH POV. L. REP. $\{$ I $6010,6705.20,7200$ and 7415 (1968).

25. This debate takes on political overtones, as indicated by Governor Regan's veto of funding for California Rural Legal Assistance Association, OEO's premier example of aggressive law reform. See Benton, Barristers' Review Finds Regan CRLA Charges Suspect, 4 CLearinghouse Rev. 465 (1971). A still more recent example is the veto of funding for the Maricopa County Legal Aid Society by Governor Williams of Arizona. That program received funding for a law reform unit during 1970, provoking the criticism of the Governor, AttorneyGeneral and the Phoenix newspapers. All the critics agreed that routine representation of the poor was admirable; it was test case litigation they found objectionable. See The Phoenix Gazette and The Phoenix Republic, April 1-6, 1971.

26. Shapiro v. Thompson, 394 U.S. 618 (1969).

27. Dandridge v. Williams, 397 U.S. 471 (1970).

28. As to the duty of a state to support its citizens with a minimum standard of essential services, see Bendich, Privacy, Property and the Constitution, 54 CALIF. L. REv. 407, 420-21 (1966); Michelman, On Protecting the Poor Through the Fourteenth Amendment, 83 Harv. L. Rev. 7 (1969); Reich, The New Property, 73 YaLE L.J. 733 (1964).

29. 60 U.S. (19 How.) 393 (1857).

30. 163 U.S. 537 (1896). 
Brown v. Board of Education ${ }^{31}$ establishes the essential value of timing in constitutional reform. Hindsight is an excellent teacher. What is difficult, but necessary, is sensing the ripeness of the hour, of measuring the gap which must be bridged from accepted wisdom to future learning at the time suit is being brought. Successful law reform litigation requires the captain's sense of the sea when he comes upon the deck.

More must be considered, however, than the legal ripeness of the issues. Of primary importance, requiring stable clients and stable facts, is the ability to keep the case alive during protracted litigation. ${ }^{32}$ In Williams $v$. Shaffer ${ }^{33}$ and Sanks $v$. Georgia ${ }^{34}$ attempts were made to challenge Georgia's requirement of a defendant's bond in eviction proceedings. Without such a bond, the tenant could not appear and defend. Both attempts aborted because the issue, which had obvious merit, became moot prior to decision by the Supreme Court. In Williams, the tenants lost possession before the Supreme Court could act; in Sanks, the legislature changed the statute ${ }^{35}$ between the time of argument and reargument. As a consequence, the substantial investment of legal talent in each case was lost.

The very urgency of the problems typically facing the poor diminishes their ability to see litigation to an end. For example, when a divorce is needed, it is often needed immediately, to provide for support and alimony, to end abuse, to exclude the errant spouse from the home or to reach him before he flees the jurisdiction. The law reform issue - in Boddie, the right to proceed without paying costs-may disappear in the face of such need. ${ }^{36}$ This has ambiguous

31. 347 U.S. 483 (1954).

32. As to legal aspects of mootness in poverty litigation, see Kates, Memorandum on the Law of Moorness, 3 CieARingmouse Rev. 213, 285 (1970).

33. 385 U.S. 1037 (1967) (denying cert.).

34. 401 U.S. 144 (1971).

35. GA. CODE ANN. § 61-303-05 (1970). Changing the underlying law to avoid an issue is not an uncommon hazard in test case litigation for the poor. One of the carliest poverty law test cases raised the right of a public housing tenant to a due process hearing prior to eviction. While the case was on appeal, the Department of HUD issued a policy directive of questionable meaning and force. The Supreme Court used the memorandum as a pretext first to remand, Thorpe v. Housing Auth., 386 U.S. 670 (1967) and then later to avoid the constitutional ground while holding for the tenant. Thorpe v. Housing Auth., 393 U.S. 268 (1969). Similarly, in Boddie, one of the State's arguments was that the problem of court fees was under consideration by the legislature. The district court, in view of this, felt constrained to defer to the legislative process. Boddie v. Connecticut, 286 F. Supp. 968,972 (D. Conn. 1968).

36. Compelling necessity may drive a litigant to beg or borrow moncy or to take rent money from a welfare stipend to resolve the problem raising the law reform issues. The issue may thus be lost, as it was for three appellants in Boddie, who paid their own costs. 
implications. A law reform case is most appealing to the Supreme Court if it dramatically illustrates the arbitrary harshness of the challenged action. Selection of a law reform vehicle should therefore reflect this, as is well typified by the suits involved in Shapiro $v$. Thompson, ${ }^{37}$ Goldberg $v$. Kelly ${ }^{33}$ and In re Gault. ${ }^{39}$ Yet those were successful only because the appellants had nowhere to turn pending appeal; their suits were against the state, and it would not compromise. ${ }^{40}$ ln contrast, much law reform for the poor must involve private litigants such as landlords and merchants. Settlement is likely with them. ${ }^{41}$ Consequently, some forms of law reform litigation require not choosing the most outrageous cases, but instead choosing those which illustrate the problem or issue in milder forms which may be preserved during an appeal. Then too, poverty is for many a transient state. Few rise, in the tradition of Horatio Alger, to great wealth. But many pass from below the magical, mystical "poverty line" into middle America. This can render moot an appeal involving poverty, such as the right to have court costs waived. ${ }^{42}$

Resilient, intransigent defendants are as important as durable clients. The common experience in the criminal process is for important issues to be viewed as bargaining tools to effect a pleabargain. ${ }^{43}$ In the civil area the practice is perhaps more pronounced, and the aim of counsel for both sides is to settle cases. Doing so does not make new law. The likelihood of settlement must be carefully assessed before making the substantial investment required by an appeal, otherwise the appeal may abort, thus sacrificing the investment in law reform. ${ }^{44}$

37. 394 U.S. 618 (1969).

38. 397 U.S. 254 (1970).

39. 387 U.S. 1 (1967).

40. However, smaller agencies, such as housing authorities, may have semi-autonomous status and limited legal resources. To the extent that a small governmental agency must retain outside counsel, a substantial drain is placed on what may already be a limited budget. This was true, for example, in Simmons v. West Haven Housing Auth., 400 U.S. 856 (1971). There the agency nearly abandoned the case until the State's Attorney-General agreed to assume the burden of representation.

41. A notahle example of a law reform case where the private defendant did not capitulate is, of course, Sniadach v. Family Fin. Corp., 395 U.S. 337 (1969). Few small loan companies (or furniture and auto dealers for that matter) can be expected to have such stamina.

42. See note 32 supra. At least one of the appellants in Boddie so moved and by 1971 could not file an affidavit of indigency although in 1968 she was very clearly poor.

43. As to the prevalence and problems of plea-bargaining, see, e.g., THE President's Commission on Law ENForcement \& Administration of 'Justice, TASK FOrCe Report: THE COURTS 9-13, 108-19 (1967).

44. It remains true, of course, that the clients' interests are paramount. An attorney's 
Another factor in determining whether a case has law reform potential is the state of the record. The law reform issue must be clearly, simply raised. Much test case litigation involves an attempt to save a case not planned from the start for law reform purposes. As a consequence, the record may be poor-an objection may not have been made, a motion may not have been timely filed, essential allegations may be missing. Even litigation designed for test case purposes may be lost because of judicial hostility to innovation..$^{45}$

A final consideration, perhaps already evident, is determining which area of the law must receive attention. The poor have an almost infinite number of recurring problems. Poverty law programs have only finite resources and so choices must be made..$^{46}$ The choice may be made on an elitist basis, the legal staff determining what is "best for the poor;" it may be made by neighborhood panels of the poor suggesting what problems are most troublesome; or it may be dictated by happenstance, by the pressures or vagaries of caseload. Perhaps the last approach is often the case. But certainly the most successful instances of poverty law reform have relied upon the most obvious factor-what seriously affects the poor in the greatest number. The repeated challenges to welfare provisions and wage garnishments, and the recently successful challenge to imprisonment for inability to pay a fine reflect this approach. This is not necessarily an elitist approach; a legal services program will respond to the problems most often coming to its offices. The response will reflect not only the needs of the poor but also the consequent, slow accretion of expertise produced by

primary obligation is to represent his clients, not make new law. See ABA, CODE of Professional Responsibility, Canons Nos. 5, 6 \& 7 (Final Draft 1969). However, the paucity of resources and the abundance of demand with respect to poverty law programs compels decisions allocating resources. The factors discussed in this article provide rational guidelines for those decisions, at least to the extent that that a program prefers to invest in test case litigation, as opposed, for example, to community education or organization.

45. Simmons v. West Haven Housing Auth., 400 U.S. 856 (1971) is a good example. There the defendant's counsel raised a series of ingenious defenses to an eviction proceeding. The trial court, however, felt they were frivolous. Stays of execution pending appeal were obtained and lost in various courts. Along the way the issue narrowed to the right to waiver of a bond on appeal, the substantive defenses becoming thereby obscured. A hostile judge entcred an inappropriate finding of bad faith in the appeal, thus clouding the one remaining issue. The Supreme Court noted jurisdiction, then dismissed as improvidently granted. The substantial efforts of counsel had thus been curbed, bridled and ultimately frustrated by the appellate process and the conditions inherent in hitigating for the poor. See Stumpf \& Janowitz, Judges and the Poor: Bench Responses to Federally Financed Legal Services, 21 STAN. L. REv. 1058 (1969). As to the general hostility of the bar, see note 2 supra.

46. See note 44 supra. 
repeated exposure of staff attorneys to a problem. If an issue affects large numbers of people, stable fact situations and sympathetic clients can be sought out from the volume of pending cases. Mootness can be avoided by suing on behalf of several clients; others can be substituted as needed once the case is underway. By choosing a problem that affects a large number of people, the likelihood of success on the merits is enhanced. The Supreme Court in cases such as Shapiro $v$. Thompson, ${ }^{47}$ Sniadach $v$. Family Finance Corporation ${ }^{48}$ and even Dandridge $v$. Williams $s^{49}$ heavily emphasized the importance to the poor of the issues involved.

In summary, then, test case litigation for the poor requires certain conditions. The state of the law must be promising. The factual situation must be stable. Both plaintiffs and defendants must have the capacity to litigate a case to conclusion. The case must be such that the important issues can be clearly raised in the record, distilled and maintained for appeal. Finally the issue to be litigated must involve a recurring problem, affecting large numbers of clients in a serious fashion.

\section{The Appropriateness of Boddie as Test Case Litigation}

The initial inquiry in framing Boddie was not whether the problem of costs was important; rather, the question was whether the law was favorable. There was ample authority for relieving the poor of court costs in the criminal areas. Perhaps the strongest case to support similar relief in the civil area was Griffin $v$. Illinois, ${ }^{50}$ holding that an indigent must be afforded a transcript for a criminal appeal. Since there was no majority opinion, the broad language in Griffin to the effect that the kind of trial a man gets cannot be made to depend upon the size of his purse could only be said to represent the view of a

47. 394 U.S. 618 (1969).

48. 395 U.S. 337 (1969).

49. 397 U.S. 471 (1970).

50. 351 U.S. 12 (1956). The appellants also developed a due process argument, based upon the first amendment guarantee of the right to petition for redress of grievances, see notes 115-16 infra and accompanying text. In the early analysis of the case in 1968, this argument did not seem as strong as the equal protection argument based on Griffin. This was in part because the right to petition cases had not involved a "poverty" context. See United Mine Workers v. lllinois Bar Ass'n, 389 U.S. 217 (1967); Brotherhood of R.R. Trainmen v. Virginia State Bar, 377 U.S. 1 (1964); NAACP v. Button, 371 U.S. 415 (1963). By 1970, the due process argument had been substantially strengthened by new case law with clear poverty implications. See notes 122-26 infra and accompanying text \& note 153 infra. 
minority of the Court. Also, cases ${ }^{51}$ interpreting Griffin had repeatedly and carefully limited it to criminal contexts. Still, it was clear that a case challenging civil court costs ${ }^{52}$ might draw sustenance from Griffin if it involved an imposition by the State upon an indigent in a matter of great personal urgency.

To increase the implications of such a case, the indigent would lrave to be cast in the role of plaintiff. It is in such a role that court $\operatorname{costs}^{53}$ are most often a hindrance to the poor. And the role of plaintiff is crucial if a litigant is to take the initiative and effect law reform; otherwise, control of the litigation-its pace, scope and result-passes to the adversary.

The poor are plaintiffs in a considerable range of litigation. Suits against welfare departments for denial of benefits and against housing autliorities for refusal of admission are standard fare in a poverty law office. Sucli cases are often so complex and confused that they would have been poor vehicles to raise the court costs issue. Too, suits against public entities, ${ }^{54}$ because they were so closely akin to Griffin would, if court costs were waived, have only limited implications for the vast bulk of litigation by the poor with private entities.

In the area of private litigation, domestic relations suits seemed most promising for raising the court costs issue. Of all types of litigation in which they are participants, the poor are most often plaintiffs in divorce proceedings..$^{55}$ Not only is divorce of crucial importance to fundamental interests, such as support, custody and remarriage, but entitlement is often clear. Most divorces are uncontested. This means the waiver of costs issue could be raised in a divorce proceeding with little fear that it would be obscured by contested factual allegations or substantive rights. If some of the

51. E.g., Long v. District Ct., 385 U.S. 192 (1966); Smith v. Bennett, 365 U.S. 708 (1961); Burns v. Ohio, 360 U.S. 252 (1959).

52. Griffin's application to civil collateral attacks on criminal proceedings is well settled. See cases cited in note 51 supra.

53. OEO provided only minimal funding for expenses such as depositions and transcripts, the kind of costs a defendant would incur. Thus the court costs problem was peculiarly that of plaintiffs, for whom there were virtually no federal funds to pay fees and service expenses. See note 16 supra and text accompanying notes 127-34 infra.

54. See notes 221-23 infra and accompanying text.

55. Brief for National Legal Aid and Defender Association as Amicus Curiae at Appendix B, Boddie v. Connecticut, 401 U.S. 371 (1971) indicated that divorce cases in 1969 averaged approximately twenty to thirty percent of legal service program caseloads. These figures reflect only the suits actually brought. The percentage of would-be divorce litigants among applicants for service actually is higher, since court cost barriers undoubtedly prevented filing many suits. See text accompanying notes $127-34$ infra. 
plaintiffs had desertion grounds for their divorces, the likelihood of settlement and pressures upon the clients for immediate relief pending appeal could be minimized.

It seemed necessary to choose clients whose grounds for divorce had persisted, along with the client's interest in obtaining a divorce, for several months and whose suits would not be contested. Clients were also chosen in order to raise the issue of payment of service fees clearly. To avoid dispute as to indigency, each of the clients was a recipient of welfare. Four of the plaintiffs were black, in part because poverty is disproportionately a problem of the $\mathrm{Negro}^{56}$ and, in part, in order to be able to draw upon the considerable body of literature available concerning the Negro family..$^{57}$

Suit was then brought.

\section{Framing the CASE}

\section{The Forum}

The vast bulk of poverty law reform litigation is initiated in federal court. Except for such states as New York or California, most state court systems are generally conservative, particularly where, as in Boddie, their processes are being challenged. If a decision will ultimately have to come from the United States Supreme Court, as was anticipated with Boddie, it is best to get there from the most favorable trial forum in the shortest time. This usually means starting in federal court. ${ }^{5 s}$

56. See. e.g., M. Harrington, The Other America 63-82 (1962); The Kerner COMMISSION REPORT, note 15 supra, at 251-65.

57. Marriage and divorce patterns have been the subject of considerable study and research. Particularly is this true of the poor and Negroes, for whom the unavailability of divorce effectively prevents new marriages and new beginnings, perpetuating instead instability and poverty. In addition to the authorities cited note 17 supra, see J. BERNARD, REMARRIAGE 306-18 (1956); J. Despert, Children of Divorce 9-26 (1953); W. Goode, The Family 92, 94, 101-02 (1964); Goode, Pressures to Remarry, in A MOdern Introduction to the FamiLy 316 (N. Bell \& E. Vogel eds. 1960); Lutz, supra note 17, at 61-62, 101; Pollak, The Broken Family, in Soctal Worx and Social Problems 321 (N. Cohen ed. 1964); Glasser \& Navarre, Structural Problems of the One-Parent Family, 21 J. Soc. Issues (No. 1) 98, 106-07 (1965); Miller, Implications of Urban Lower-Class Culture for Social Work, 33 SOC. SERv. REv. 219, 226-28 (1959); Schlesinger, The One-Parent Family: An Overview, 15 FAM. L. Co-oRD. 133, 134-35 (1966). The conclusion of these writers is that broken homes can be mended by divorce, followed by remarriage. Absent divorce, a broken home constitutes an unstable, unhappy, shattered, unproductive social unit. The impact on mother and children can be disastrous. See also J. Bernard, Marriage and Family among Negroes (1966); Office of Policy Planning and Research, Departaient of Labor, The Negro famlly: The Case for National action (THE MOYNIHAN REPORT) (1965).

58. Federal jurisdiction could be rested upon 28 U.S.C. § 1343(3) (1964), providing for 
However, a predicate to federal jurisdiction, in a situation similar to Boddie, is some form of state court action. There are two reasons for this. First, it is necessary to establish that the litigant has been deprived of a constitutional right under "color of state law." In Boddie, the refusal of state courts to waive the filing fee, based upon a state statute requiring filing fees, provided the requisite "state action" for establishing federal jurisdiction. ${ }^{59}$ Secondly, at least some gesture toward "exhausting state remedies" seemed desirable. There is no requirement under the civil rights acts that a litigant exhaust his state remedies. ${ }^{60}$ Nevertheless, such principles as "comity," "abstention" and "exhaustion of state remedies" are part of the "co-operative federalism" leading federal courts to defer to state courts. ${ }^{61}$ These phrases reflect more than federalism, involving as well the general reluctance of any court to embark upon unchartered constitutional seas. $^{62}$

original jurisdiction of any action "[t]o redress the deprivation, under color of any State law, statute, ordinance, regulation, custom or usage, of any right, privilege or immunity secured by the Constitution . . . A cause of action may be stated under the parallel provision, 42 U.S.C. $\S 1983$ (1964), providing redress against any "person who, under color of any statute, ordinance, regulation, custom, or usage, of any State or Territory, subjects, or causes to be subjected, any citizen of the United States or other person . . . to the deprivation of any rights, privileges, or immunities secured by the Constitution . . . ." These statutes are obviously quite broad and have served as the means of obtaining federal relief in much of recent poverty litigation. See, e.g., Goldberg v. Kelly, 397 U.S. 254 (1970); Shapiro v. Thompson, 394 U.S. 618 (1969).

59. It should be noted that while state action is required under 42 U.S.C. $§ 1983$ (1964), it is not required by two companion provisions, id. $\S \S 1981,1982$ (1964). See Jones v. Mayer, 392 U.S. 409, 436-37 (1968); Saunders v. Dobbs House, 431 F.2d 1097 (5th Cir. 1970); Waters v. Wisconsin Steel Works of Int'l Harvester Co., 427 F.2d 476, 483 (7th Cir. 1970). But see Cook v. Advertiser Co., 323 F. Supp. 1212 (M.D. Ala. 1971).

60. See Damico v. California, 389 U.S. 416 (1967); MCNeese v. Board of Educ., 373 U.S. 668 (1963); Monroe v. Pape, 365 U.S. 167 (1961).

61. The basic federal court policy of non-interference in state affairs has been best devcloped in the "abstention" doctrine. See Knowlton, The Federal Anti-Injunction Statute and the Related Abstention Doctrine, 21 S.C.L. Rev. 313 (1969); Comment, Recent Developments in the Doctrine of Abstention, 1965 DuKE L.J. 102; Comment, The Exercise of the Abstention Doctrine and Its Consequences: A Clarification, 6 DuQ. L. ReV. 269 (1967); Notc, FederalQuestion Abstention: Justice Frankfurter's Doctrine in an Activist Era, 80 HARV. L. REv. 604 (1967). See note 104 infra.

62. For example, see Eisen v. Eastman, 421 F.2d 560 (2d Cir. 1969), suggesting that a plaintiff under $\S 1983$ must at least exhaust his administrative remedies to the point of seeking review of a low level decision by a superior official. To the same effect, see Smith v. Board of Comm'rs, 380 F.2d 632 (D.C. Cir. 1967). It would seem this is not so much an "exhaustion" requirement as it is a matter of clearly establishing the existence of state "action." More troublesome is the suggestion in both Smith and Eisen that federal civil rights actions are proper only if the state remedy is ineffective. Some oblique support may be found for this in McNecse v. Board of Educ., 373 U.S. 668 (1962), but the idea is hardly consistent with the purpose of the Reconstruction legislation. See Monroe v. Pape, 365 U.S. 167 (1961). 
State court divorce papers were drafted in Boddie. These were in the customary form and were accompanied by motions to waive the filing and service fees, to which financial affidavits were attached. All of these papers were mailed to the clerk of the Superior Court for New Haven County. Refusing to accept them, he returned the documents, so that the applications to waive costs could not even be argued before a judge. ${ }^{63}$ The clerk's action was taken up in chambers with the judge sitting on the Domestic Relations Court who refused to list the matter for argument, thus allowing the clerk's action to stand. According to Connecticut practice there was then no case in court and no way to appeal to the Connecticut Supreme Court. The only action possible was to seek relief through informal channels to the office of the administrator of the courts, a Justice of the Connecticut Supreme Court, who denied the requested relief.

The stage was thus set to proceed in federal district court. The benefits sought in the federal system, a favorable forum and expedited review by the Supreme Court, may be increased by framing the case as one appropriate for a three-judge court ${ }^{64}$ and by including a request that such a court be convened in the prayer for relief. Having a threejudge court diminishes the role that one unresponsive judge might play. Since the judge to whom the application is presented is a member of the panel,$^{65}$ he can be selected with the case in mind. Also, personality conflicts can be minimized since another judge must be from the court of appeals. ${ }^{66}$ Then too, a decision of a three-judge district court is reviewed directly by the Supreme Court ${ }^{67}$ without intermediate review by the court of appeals. ${ }^{68}$ While the right to

63. While the clerk's action was sufficient to constitute the requisite "state action" for purposes of establishing federal jurisdiction, further proceedings were necessary to clearly exhaust possible state remedies. A danger in this was that some judge might overrule the clerk, entertain arguments, and thereby delay the proceedings. Therefore, further proceedings, while genuine, were calculated to be ineffectual.

64. 28 U.S.C. $\& 2281$ (1964), provides that a three-judge district court must hear a suit seeking an injunction on the ground that a state statute is unconstitutional. As to three-judge courts generally, see Currie, The Three-Judge District Court in Constitutional Litigation, 32 U. CHr. L. Rev. 1 (1964); Note, Three-Judge District Courts: Some Problems and a Proposal, 54 Cornell. L. Rev. 928 (1969); Comment, The Three-Judge Federal Courts in Challenges to State Action, 34 TenN. L. Rev. 235 (1967); Comment, The Three-Judge District Court in Contemporary Federal Jurisdiction, 41 WASH. L. REv. 877 (1966). See note 86 infra.

65. 28 U.S.C. § 2284 (1964). See note 64 supra.

66. 28 U.S.C. \& 2284 (1964).

67. Id. §1253.

68. A refusal to convene a three-judge panel is reviewed by the court of appeals. See Shackman v. Arnebergh, 387 U.S. 427 (1967); Note, Reviewing the Grant of a Three-Judge Court, 69 CoLum. L. REv. 145 (1969). See also note 64 supra. 
Supreme Court review of a three-judge court decision is a statutory right of appeal, not dependent upon the Court's grant of a discretionary writ, the Supreme Court seems to exercise the same discretion in noting probable jurisdiction on appeals as in granting or denying petitions for certiorari. Still, the prospect of a direct appeal from a three judge district court panel offers the best hope of expeditious review.

Thus the complaint in Boddie was drafted so as to challenge the constitutionality of the state statute as applied and the court was requested to convene a three-judge panel. The statute itself had to be called into question because review of official action alone would not require a three-judge panel. ${ }^{69}$ It was necessary, however, to challenge the statute as applied, since the fee and service of process requirement did not-on their face-discriminate against the poor.

\section{The Parties}

Boddie was brought as a class action. There are several reasons why this vehicle is valuable for law reform. One is that any member of the class may take advantage of the judgment. Another, and more important reason in Boddie, is that test case litigation, inevitably extending over several years, must be preserved, representing, often times, too substantial an investment or an issue to depend upon the vagaries of individual fortunes. ${ }^{70}$ Class actions enable attorneys to add new litigants as needed. ${ }^{11}$

This is not the place to develop fully the elements and requisites of class actions. The area is extremely complex. At a minimum, the class must be described and defined broadly enough to keep the litigation alive. ${ }^{72}$ Yet the class should be described as conservatively and precisely as possible, since otherwise its very existence may become a

69. Unconstitutional action of a state official does not require a three-judge panel. Phillips v. United States, 312 U.S. 246 (1941), Ex parte Bransford, 310 U.S. 354 (1940). But if the action is pursuant to a specific statute, the application of which is challenged as unconstitutional, a three-judge panel is appropriate. Poindexter v. Louisiana Financial Assistanœ Comm'n, 258 F. Supp. 158, 165 (E.D. La. 1966); Evergreen Review, Inc., v. Cahn, 230 F. Supp. 498, 502 (E.D.N.Y. 1964). See also the district court opinion in Boddie, 286 F. Supp. at 971 . See note 172 infra.

70. See notes 32-35 supra and accompanying text.

71. On class actions generally, see Dolgow v. Anderson, 43 F.R.D. 472, (E.D.N.Y. 1968);

C. WRIGHT, LAW OF FEDERAL COURTS 306-17 (2d ed. 1970).

72. As to describing a class, see Tijerina v. Henry, 398 U.S. 922 (1970); Cancel v. Wyman, 321 F. Supp. 529 (S.D.N.Y. 1970); Norwalk Core v. Norwalk Redevelopment, 298 F. Supp. 210 (D. Conn. 1968); Smith v. Hull, 285 F. Supp. 556 (E.D.N.C. 1968). 
litigated issue. And, perhaps more importantly, the breadth of the class may intimidate an otherwise favorably disposed judge.

In addition the complaint must contain allegations as to the class. This means meeting the requirements of Rule 23 of the Federal Rules of Civil Procedure. ${ }^{73}$ Whether the description of the class in Boddie met the applicable standards was never decided. The district court reserved the question of whether the suit was a proper class action, and the Supreme Court did not rule upon the issue. In any event, the plaintiffs did in fact seem to represent a class, distinct from the general population, sharing a uniform iaterest in the subject matter of the litigation and so numerous as to be not susceptible of being joined. Roughly speaking, these are the requisites of a class-action.

In any lawsuit a basic problem is determining whom to sue. Often this is a complex matter, particularly in poverty litigation, where the poor are often suing because of action by a public agency. It is sometimes difficult to determine which agency is responsible for correcting offensive conduct and who is, in turn, responsible for that agency. Areas such as welfare, public housing and urban redevelopment are best described as bureaucratic mazes. ${ }^{74}$ Identifying responsible individuals in such mazes may be an impossible task.

In Boddie, there was little difficulty identifying the defendants. But another problem, equally typical of poverty litigation, emerged-that of sovereign and judicial immunity. Two of the defendants were judges, one was a court clerk, and the fourth was the State. The State was added as a defendant in the belief that if the action could not be maintained against the others it must be maintainable against someone, and only the State was left. But the obvious problem with this theory was sovereign immunity. While the

73. See cases cited in note 72 supra as to these requirements. Generally, class actions under Rule 23 are permissible if joinder of all members is impracticable, there are questions common to the class, and the representatives are typical of the class and will faithfully represent it; and individual suits by or against class members might bind the entire class; or the defendant has acted on grounds applicable to the entire class; or the common questions of law or fact predominate over individual questions by members of the class-considering such problems as existing litigation, desirability of concentrating litigation in one forum and problems of managing the class.

74. For example, residents displaced by urban renewal and wishing to object to the failure to relocate them properly must choose among the agency staff and governing board, the city executive officers and council, state agencies and personnel, and officials of the Department of HUD. The only safe course is to sue everyone. See Norwalk Core v. Norwalk Redevelopment Agency, 395 F.2d 920 (2d Cir. 1968). It may then still be necessary to sue a private contractor. Norwalk Core v. Norwalk Redevelopment Agency, 296 F. Supp. 456 (D. Conn. 1968). 
eleventh amendment does not by its terms preclude suits against a state by its citizens, it has been so interpreted ${ }^{75}$ and the district court ultimately excluded the State..$^{76}$

As to the judges, the defense of judicial immunity was minimized by seeking only injunctive relief. 7 As to the clerk, and the judges as well, the doctrine of judicial immunity arguably did not apply, since it insulates judicial, not administrative, discretion from attack. ${ }^{78}$ Suit against the public offices occupied by these individuals would have directly offended sovereign immunity concepts. However, by bringing the suit against the individuals who occupy the office, the defense of sovereign immunity by the judges and the clerk was avoided. This stylistic distinction makes no theoretical sense but has been held to satisfy the eleventh amendment. ${ }^{79}$

All of this illogic may crumble under the pressures of recent poverty litigation seeking damages from state officials in their official capacities. ${ }^{80}$ Such suits do not simply seek proper personal conduct nor do they seek personal reimbursement from the wrongdoers. Instead they go to the very heart of sovereignty, the treasury. This may force courts to recognize suits against office-holders as being

75. Hans v. Louisiana, 134 U.S. 1 (1890). As to municipalities, the Supreme Court has said there can be no liability under § 1983 since a governmental agency is not a "person" for purposes of that statute. Monroe v. Pape, 365 U.S. 167, 191 n.50 (1961).

76. 286 F. Supp. at 968.

77. The subject of sovereign, judicial and legislative immunity from suit has been treated in many articles. See, e.g., Jaffe, Suits Against Governments and Officers: Damage Actions, 77 HARV. L. REv. 209 (1963); Mathis, The Eleventh Amendment: Adoption and Interpretation, 2 GA. L. REv. 207 (1968); Comment, Federal Comity, Official Immunity and the Dilenima of Section 1983, 1967 DUKE L.J. 741; Comment, State Governmental Corporation Imnumity from Federal Jurisdiction Under the Eleventh Amendment, 72 Dick. L. REv. 296 (1968). See also Pierson v. Ray, 386 U.S. 547 (1967) (judicial immunity); Tenny v. Brandhove, 341 U.S. 367 (1950) (legislative immunity). Injunctive relief has frcquently been granted against judicial officers and procedings.

78. The district court in refusing to dismiss the complaint emphasized that the functions performed by the seemingly judicial defendants fell into the realm of administrative activities. Hence the rationale of judicial immunity did not apply. 286 F. Supp. at 971 . See Robichaud v. Ronan, 351 F.2d 533 (9th Cir. 1965); Lewis v. Brautigam, 227 F.2d 124, 128-29 (5th Cir. 1955); Rousselle v. Perez, 293 F. Supp. 298 (E.D. La. 1968).

79. See Ex parte Young, 209 U.S. 123 (1907), the landmark decision permitting suits against states if brought against their officers. Quite obviously, this does violence to the state's immunity from suit. See note 76 supra. The alternative-absolute immunity-however would do greater violence to democratic theories as to the accountability of government.

80. Compare Sostre v. Rockefeller, 312 F. Supp. 863 (S.D.N.Y. 1970) with Westberry v. Fisher, 309 F. Supp. 12 (D. Me. 1970). See Levy, The Aftermath of Victory: The Availability of Retroactive Welfare Benefits Illegally Denied, 3 CLEARINGHouse REv. 254, 285, 330 (1970). 
against the sovereign and compel a rethinking of the sovereign immunity gloss upon the eleventh amendment.

\section{The Complaint and Prayer for Relief}

The plaintiffs' position in Boddie was simple. They were poor, wanted divorces, had submitted their papers to the Connecticut courts, but the papers were returned because no filing fees were-or could be-paid. Plaintiffs felt they had been denied due process and equal protection. Thus the case met one of the requisites of good test litigation-factual simplicity. Procedural simplicity could also be anticipated, since the appropriate response by the defendants would be a motion to dismiss, admitting the facts alleged. Thus the constitutional issue would be clearly raised in the record and preserved on appeal.

Two pieces of paper - a complaint and a motion to dismiss-constitute a thin record on which to make hard law. The Supreme Court has many times indicated the need for facts to flesh out a record,,$^{81}$ to provide a feeling for the underlying interests at stake. The complaint was therefore accompanied by the financial affidavits which had been previously submitted to the Connecticut courts ${ }^{82}$ giving basic information such as income, assets, expenses, debts and number of dependents. Thus a record existed for Supreme Court review as if there had been a hearing, only, of course, it had been drafted by plaintiffs and had not been muddied by cross-examination.

The affidavits were intended also to serve a somewhat related function. The meaning of "indigency" or "poverty" for purposes of

81. Perhaps a good example involving drug addiction is Powell v. Texas, 392 U.S. 514 (1968), where the litigants sought a Supreme Court decision consonant with several lower court opinions holding that alcoholism was a disease, a status which could not be the basis of a criminal conviction. The parties hoped to build upon Robinson v. California, 370 U.S. 660 (1962). But the trial record consisted of only fourteen pages, reflecting a cooperation between prosecution and defense to bring the case to the Supreme Court. It was apparent that the judge had tailored his findings to frame the precise issues the parties sought to raise. The Supreme Court declined to rule on a record which had not been the subject of extensive adversary development. See also Flast v. Cohen, 392 U.S. 83 (1968), and Baker v. Carr, 369 U.S. 186 (1962), for the emphasis the Supreme Court places on the role of the parties in developing a justiciable issue.

82. Brief for Appellant at Appendix 11-28, 401 U.S. 371 (1971) [hereinafter cited as Brief]. The facts in these affidavits are summarized in the majority opinion in Boddie, 401 U.S. at 372 . Additional affidavits were filed two and one-half years later, following reargument. See text accompanying notes $127-34$ infra. 
in forma pauperis litigation is far from clear ${ }^{83}$ and bureaucratic definitions" of the "poverty line" are not very helpful. With this in mind, the plaintiffs in Boddie were limited to those receiving welfare assistance, which, it was specifically alleged, does not include an allotment for legal expenses. This posed an opportunity for the courts to establish an objective judicial test of poverty by, in effect, accepting prior administrative determinations. Also, the defendants could

83. Adkins v. E.I. DuPont deNemours \& Co., 335 U.S. $331,339-40$ (1948), contains the most extensive Supreme Court discussion on the subject:

We cannot agree with the court below that one must be absolutely destitute to enjoy the benefit of the statute. We think an affidavit is sufficient which states that one cannot because of his poverty "pay or give security for the costs. . . and still be able to provide" himself and dependents "with the necessities of life." To say that no persons are cntitled to the statute's benefits until they have sworn to contribute to payment of costs, the last dollar they have or can get, and thus make themselves wholly destitute, would be to construe the statute in a way that would throw its beneficiaries into the category of public charges.

The Court went on to say:

The public would not be profited if relieved of paying costs of a particular litigation only to have imposed on it the expense of supporting the person thereby made an object of public support. Nor does the result seem more desirable if the effect of this statutory interpretation is to force a litigant to abandon what may be a meritorious claim in order to spare himself complete destitution.

In only one case has the Supreme Court reversed a lower court and ruled that a petitioner was indigent in the constitutional sense and therefore entitled to proceed in forma pauperis in a criminal trial. Seals v. Alabama, 380 U.S. 254 (1965). See also Bramlett v. Peterson, 307 F. Supp. I311 (M.D. Fla. 1969); Cuevas v. Wilson, 264 F. Supp. 65, 72 (N.D. Cal. 1966); In re Trevithick, 260 F. Supp. 852,853 (D.S.D. 1966). In Bramlett the Court said:

The determination of indigency rests in the sound discretion of the court, but it should take into consideration whether the accused has a family or other dependents and how many, if the accused is presently employed or is on welfare, whether he has income while in custody, what amount, if any, he has in checking or savings accounts, the extent of any indebtedness, whether he is incarcerated or free on bond, and whether he has adequate assets not presently encumbered or otherwise unavailable. 307 F. Supp. at 1323.

See text accompanying notes 180-210 infra for the standards of indigency reflected in the opinions of Justices Black and Harlan in Boddie. See also notes 180-83 infra and accompanying text.

84. There are, of course, a number of agencies which use indigency as a measure of eligibility for services. The most relevant for in forma pauperis purposes would be the standards used by legal services programs. See Silverstein, Eligibility for Free Legal Services in Civil Cases, $44 \mathrm{~J}$. URB. LAw 549 (1967). Also useful would be cost of living standards used to determine welfare stipends. Less useful would be bureaucratically defined figures, such as those developed by the Bureau of Labor Statistics, the Social Security Administration, or the United States Department of Agriculture. See Orshansky, Counting the Poor: Another Look at the Poverty Profile in Poverty in America 67 (L. Ferman, J. Kornbluh \& A. Haber eds, 1968); Rein, Problems in the Definition and Measurement of Poverty, in id. at 116. Any standard is inevitably subjective, relative, and affected by the social or bureaucratic values of the person developing or applying it. 
hardly muddy the record by denying the plaintiffs' poverty claim, since it had already been accepted by the state for welfare purposes.

The prayer for relief is often the most neglected aspect of a pleading. Yet it is obviously the most important and should reflect every aspect of the theory expressed in the complaint. In Boddie the prayer requested the court to convene a three-judge panel; declare the practice and statutes concerning fees and service as unconstitutional "when applied to these indigent plaintiffs and all others of the class they represent;" and issue an injunction requiring the defendants to accept plaintiffs' papers without fees, permit plaintiffs to proceed, and arrange service of proeess or notice by publication for them. The prayer closed by asking similar relief as "to future divorce proceedings initiated by other members of the class."

The request for the declaratory judgment may deserve some brief comment. Declaratory relief ${ }^{85}$ was needed with respect to service of the divorce papers, since the only issue clearly raised by the defendants' action had been the propriety of waiving filing fees. The case had not advanced far enough to prompt a refusal by the state to effect service of process or publication. Yet that aspect of the case was clearly crucial if the poor were to be enabled to sue in forma pauperis. It would have made little sense to litigate thc waiver of fees issue, winning it after several years on appeal, only to face a similar barrier in the expense of service or publication, necessitating a similar case, subsequent appeal and delay.

The district court ordered that a three-judge court be convened. Although the governing statutes do not appear to provide the district court with any discretion in the matter, a single judge may inquire into the substantiality of the allegations before convening a three-judge court. ${ }^{86}$ Such inquiry was not made in Boddie, presumably because

85. Pursuant to 28 U.S.C. $\$ 2201$ (1964). As to the necessity for a present, existing controversy to support a declaratory judgment action, see Public Workers v. Mitchell, 330 U.S. 75 (1947); cf. Adler v. Board of Educ., 342 U.S. 485 (1952); Nashville C. \& St. L. Ry. v. Wallace, 288 U.S. 249 (1933).

86. See, e.g.. Jones v. Branigin, 433 F.2d 576 (6th Cir. 1970); Bistrick v. University of S.C., 319 F. Supp. 193 (D.S.C. 1970); Waier v. Schmidt, 318 F. Supp. 22 (E.D. Wisc. 1970). There is of course no need to convene a three-judge panel if no substantial federal question is raised. Bailey v. Patterson, 369 U.S. 31 (1962). However, the statute providing for three-judge courts apparently contemplates that the district judge receiving the application will routinely transmit it, so that the panel may meet and itself pass upon the substantiality of the question raised. Leaving that question to one judge defeats the purpose of three-judge courts and may lead to questionable results. See, e.g., McCall v. Shapiro, 292 F. Supp. 268 (D. Conn. 1968). This increased "screening" of cases is doubtless a reaction to the dramatic increase in $\S 1983$ cases 
the substantiality of the allegations was apparent on the face of the complaint.

This was the case as submitted to the district court.

\section{The District Court OPINION}

The responsive pleading by the state was a motion to dismiss, alleging several grounds. Certain procedural points were raised. The district court rejected the state's argument that a three-judge panel should not be convened since the plaintiffs had challenged the constitutionality of a statute only as applied. ${ }^{87}$ Defendants also claimed judicial and sovereign immunity. The former was rejected, but the latter was sustained as to the State of Connecticut. ${ }^{88}$ Then, of course, the defendants maintained that plaintiffs had not stated a claim upon which relief could be granted, thus raising the central issue in the case. ${ }^{89}$

Plaintiffs relied upon an equal protection approach, grounded upon Griffin, and a due process argument, stemming from $N A A C P$ y. Button ${ }^{90}$ and other cases which had held that the first amendment right to petition for redress of greivances applied to the states. 11 The defendants, in essence, attempted to distinguish Griffin as a criminal case and Button as involving fundamental rights, in contrast to divorce. They also offered several justifications for Connecticut's system of court fees.

The central question, the district court said, was whether a state may limit "access to its civil courts and particularly in this instance, to its divorce courts, by the requirement of a filing fee or other fees which effectively bar persons on relief from commencing action therein." "92 The court noted that on a motion to dismiss it must treat the allegations of the complaint as being true; therefore, it assumed that at least some of the plaintiffs were effectively barred from bringing suit by the filing fee. ${ }^{93}$ It then added, significantly, that "[s]ince anyone who pays the fees may at least file his complaint, it is

since Monroe v. Pape, 365 U.S. 167 (1961), particularly in the poverty law reform area. See notes 64-69 supra and accompanying text.

87. 286 F. Supp. at $970-71$.

88. Id.

89. Id. at $970,972$.

90. 371 U.S. 415 (1963).

91. See note 50 supra.

92. 286 F. Supp. at 972.

93. Id. 
plain that there is in effect a classification of prospective civil suitors between those able to afford the court costs and those unable to afford them."

The court, however, went on to deny the plaintiffs relief. Although it is difficult to distill the court's reasoning, it can fairly be summarized as follows. Reliance upon Griffin and the cases following it was, in the district court's view, misplaced. "[T] differences between the right to freedom from capital punishment or imprisonment and the right of access to civil courts to adjudicate claims to money or property or adjust marital status." 95 The court noted, "[w]e have not yet gone so far as to hold that no state services may be conditioned on payment of fees. . . ."96

The court asserted that the state had at least two legitimate purposes for court fees: first, "providing financial support for the court establishment (perhaps one-fifth of its cost in Connecticut, we are told)," and second, "discouraging resort to litigation in purely frivolous matters, which might much more often be filed by indigent and affluent alike if the service was entirely free from cost." ${ }^{\text {g7 }}$ The state's claim that fees discouraged litigation and therefore served "the state's particular interest in the preservation of the family" was, however, rejected. The court commented that "the legislation under attack reveals no such intention, since the fee is the same in divorce actions as in other civil actions." 98

The court found also that due deference for cooperative federalism required it to "hestiate to act . . . until the ordinary political processes have an opportunity to function in normal course." constrained to give the state an opportunity to legislate, since its failure to do so might have simply been the product

not of considered choice or deliberate classification, but rather of inertia born

94. Id.

95. Id. The caurt further declared:

There are distinctions between the cases involving imprisonment, denjal of voting rights and ordinary civil actions. The relative importance of the subject with respect to which equality is sought must also be taken into account. The right to freedom from unjust imprisonment and the right of franchise were of particular concern to the framers of the Constitution and Bill of Rights in the post-Civil War amendments. Moreover, in the criminal, habeas corpus and eviction cases there is some direct state action involved .... Id. at 973 .

96. Id. at 972.

97. Id. at 973.

98. Id. at 974 n. 6.

99. Id. at 973. 
of lack of existence of the problems of the indigent in present proportions, or at least lack of recognition of their present extent. . . . .00

Related to this concern was the court's fear that the complexity of the problem was beyond the competence of judicial relief:

Militating against striking down the present fee legislation by judicial fiat is the extreme difficulty of judicial determination of the course the state should be required to follow. ${ }^{101}$

Various means of granting relief were available, through relief agencies and other sources within the state governmental framework. The court was unclear as to whether a state court should be required to waive the court fees and whether the state should pay for other "quite essential costs" such as service of process fees, or fees for service by publication, or investigative and legal services.

Essentially, then, the court thought the plaintiffs had asked it to venture into a political area or, if not an exclusively political area, then one of sufficient complexity to require the court to defer to state legislative decision. The court concluded by saying that "[w]] should rather leave this to correction by political process through legislative action, which may reach a more satisfactory result more speedily than the presently available machinery the courts can effectively accomplish." 102

Certain aspects of the district court opinion were of particular significance in preparing the appeal to the Supreme Court. First, the trial court said nothing concerning plaintiffs' due process argument. Nowhere is Button cited or is the right to petition for redress mentioned. This reflects a curiously narrow view of the case. More importantly, it pointed up a deficiency in presentation by counsel. Second, the fundamental nature of marriage, procreation and divorce had to be developed more thoroughly, since the district court, in weighing flimsy legislative justifications against the plaintiffs' need for divorces, had favored the former. ${ }^{103}$ Third, the equal protection argument needed strengthening to establish the relationship between Griffin and the plaintiffs' position. In Boddie, as in Griffin, the state forced litigants to go to court for relief; in both, relief could be found only in court; in both, matters involving fundamental interests and liberty were at stake; and in both the state was denying substantive
100. Id.
101. Id.
102. Id. at 974.
103. Id. at 973. 
benefits and access to the courts by reason of poverty. This analysis did not appear in the district court's opinion. Finally, some attention was required as to the district court's limited view of its competence and its expansive view of the difficulty of the issue posed. This problem had not been anticipated in the briefs, an omission which, in retrospect, is inexplicable. Obviously court fees have traditionally been a matter of legislation, not court decision. Courts dealing with such matters traditionally speak in terms deferential to the legislature. Then too, this was a federal court dealing with state legislation in a civil rights context; the tradition of federal comity was plainly involved. ${ }^{105}$

\section{Presentation to the Supreme Court}

In September, 1968 the Boddie appeal to the United States Supreme Court was filed. A jurisdictional statement was submitted and probable jurisdiction was noted in June, 1969.105 The case was argued in December, 1969 and later, in June, 1970, was scheduled for reargument. ${ }^{106}$ Reargument was heard in November, 1970 and in March, 1971 the Supreme Court reversed the district court. ${ }^{107}$ Three years passed from bringing suit to a favorable decision.

\section{The Argument}

The equal protection argument, of course, relied upon Griffin and subsequent cases that had established the general proposition that economic discrimination was violative of equal protection. ${ }^{108}$ The appellants argued that Griffin involved broad issues of constitutional significance not limited to criminal matters. Even if semantics were to govern and substance were to be ignored, then the appropriate label for the Griffin line of cases was "civil," since in each case the criminal

104. See notes 60-62 supra and accompanying text. Federal comity and deference are the reasons for the continued vitality of the exhaustion of remedies doctrine in civil rights litigation. See notes 57-62 supra.They also raise problems of abstention where state law is unclear, Railroad Comm'n v. Pullman Co., 312 U.S. 496 (1941), absent special circumstances, Dombrowski v. Pfister, 380 U.S. 479 (1965). The basic policy of federal comity also prompted the anti-injunction act, 28 U.S.C. $\$ 2283$ (1964), recently given new vigor by the Supreme Court's decisions in Younger v. Harris, 401 U.S. 37, 53 (1971); Boyle v. Landry, 401 U.S. 77, 81 (1971); Samuels v. Mackell, 401 U.S. 66 (1971).

105. 395 U.S. 974 (1969).

106. 399 U.S. $922(1970)$.

107. 401 U.S. 371 (1971).

108. Shapiro v. Thompson, 394 U.S. 618 (1969); McDonald v. Board of Election Comm'rs, 394 U.S. 802, 807 (1969); Harper v. Virginia Bd. of Elections, 383 U.S. 663 (1966). 
process had ended and civil review, by appeal or collateral attack, had begun. In any event, the civil-criminal dichotomy was irrelevant to equal protection problems since the fourteenth amendment does not distinguish between civil and criminal cases. ${ }^{109}$

In response to appellee's argument that Griffin may be limited to cases where the state is a "participating adversary," appellants argued ${ }^{110}$ that Connecticut was a participant because its fee system barred the appellants from the courts while its divorce laws prevented them from resolving their marital affairs privately. Since the state itself had declared marriage and divorce to be so important as to be affected with a public interest, divorce was of "sufficient weight on the scales of justice" to involve the equal protection clause."11

Appellants argued that the need to conserve funds, to raise additional funds, or to discourage frivolous litigation did not justify the State's discrimination. ${ }^{112}$ In addition, appellants contended the case involved "suspect criteria"-poverty-and therefore the state must show a compelling state interest rather than merely showing a rational basis to justify the classification. ${ }^{113}$ Since the fee barriers either made no sense, or could be replaced by alternatives, no such interest existed. ${ }^{14}$

109. Brief 16-23; Reply Brief for Appellant at 5-10, Boddie v. Connecticut, 401 U.S. 371 (1971) [hereinafter cited as Reply Brief]. The extent of time and space devoted by the parties to Griffin is significant in the light of what the Supreme Court chose to do with that case. See note 153 infra.

110. Brief 16-23.

111. The state also claimed that Griffin could be distinguished because it involved personal liberty. Yet, appellants argued, their freedom was also at stake. And their rights to re-marriage and procreation were involved as well. Such rights, they argued, were fundamental. Appellees contended:

Appellants' status is necessarily controlled by a precedent action volumarily done. For divorce, the factor is marriage. Appellees urge that there is no constitutional right to be extracted from a predicament of one's own creation. Brief 11 .

The obvious answer was that every criminal, by a voiuntary act of crime, is accorded a vast panoply of constitutional rights and that "i]lustice would be strangely skewed if courts were open to felons, yet closed to those who keep the law and honor it by seeking justice in the courts." Reply Brief 8.

112. Since the poor were not providing court revenue, opening the courts to the poor would not diminish existing revenue; also, there was little likelihood-and no evidence-that the increase in litigation would require additional personnel or facilities. The only litigation which would be discouraged by the fees was that of the poor, and there was no reason to belicve their suits would be more frivolous than those of the affluent. Brief 38-49.

113. Brief 38, relying upon Shapiro v. Thompson, 394 U.S. 618 (1969).

114. The state argued it was not required to show a compelling state interest to justify imposing court costs on the poor. It sought to distinguish the cases establishing such a requirement on the ground that in those cases the state had been a party and could directly affect 
Appellants' due process argument was similar to the equal protection argument. Here, too, appellants were claiming a denial of access to the courts. But the claim of constitutional right was tied directly to the first amendment guarantee of the right to petition for redress of grievances, a guarantee applied to the states by the fourteenth amendment. While the cases on which this argument was based ${ }^{115}$ were assembly cases, involving groups, the purpose of assembly in those cases was to assert the right to petition, the very right claimed by the appellants. Even though the appellants had no constitutional right to a divorce, they had a right to seek to petition for a divorce. ${ }^{116}$ The right to petition was itself constitutionally assured, quite apart from whether the relief sought was constitutionally guaranteed.

Certain aspects of the due process argument were emphasized by appellants, distinguishing it from their equal protection position. While the equal protection argument might fail if the interest involved was not significant or serious enough to be constitutionally cognizable, in contrast, appellants claimed, any denial of the right to petition for redress was constitutionally cognizable, since the right to sue was explicitly guaranteed by the first amendment. ${ }^{117}$ Then, too, the equal protection argument had implications beyond simply getting into court-relating also to appointed counsel and, indeed, to fees unrelated to court proceedings. But the due process argument related narrowly to the right to seek a hearing in court.

The district court had said that denial of divorce does not have the grave consequences accompanying incarceration. Building upon this, the state argued before the Supreme Court "the Griffin doctrine should not be extended to include divorce, since divorce does not have sufficient weight on the scale of justice." 118 Appellants' response was that while there was no constitutional right to a divorce, still marriage, procreation, ${ }^{119}$ and the right to petition for redress of

the outcome. But in those cases the state occupied the same position as the appellees, who were Connecticut's agents. The issue was the same-whether the state could deny benerits by arbitrarily classifying its citizens.

115. United Mine Workers v. Illinois Bar Ass'n, 389 U.S. 217 (1967); Brotherhood of R.R. Trainmen v. Virginia, 377 U.S. 1 (1964); NAACP v. Button, 371 U.S. 415 (1963).

116. Reply Brief 4.

117. Brief 29.

118. Id. at II-12.

119. Levy v. Louisiana, 391 U.S. 68 (1968); Loving v. Virginia, 388 U.S. I (1967); Griswold v. Connecticut, 381 U.S. 479 (1965); Skinner v. Oklahoma, 316 U.S. 535 (1942). 
grievances were constitutionally protected interests. Such matters could not, for equal protection purposes, be unequally conditioned, nor for due process purposes irrationally or unfairly limited. Moreover, fee barriers to divorce have far-reaching consequences. The rate of divorce among the poor, especially Negroes, is the lowest in society. Studies have indicated this is due to the cost of divorces. Deterring divorces by such means does not strengthen the family or prevent desertion, which has a high rate among the poor. Fee barriers do, however, prevent remarriage and the formation of new, stable family units, leaving a void filled by unstable, illegal liaisons. ${ }^{120}$ The barrenness of such homes is self-evident. The relationship between these broken, economically depressed, unhappy homes and juvenile delinquency seems equally self-evident.

This, then, is a summary of the position ${ }^{121}$ which the parties in Boddie submitted at the time of the first argument in 1969.

\section{The Reargument}

Boddie was initially argued in December, 1969 and in June, 1970, scheduled for reargument, which took place in November, 1970. A number of cases in the poverty, criminal and first amendment areas were similarly rescheduled with no reason being given. It was assumed that the Court, consisting of eight members at the time of initial argument, had been deadlocked on these matters. The ultimate vote in Boddie of eight to one suggests this was not the reason, but no other explanation has come to light.

At the time of reargument Boddie seemed in jeopardy. Chief Justice Earl Warren had been replaced by Warren Burger and Harry Blackmun had replaced Justice Fortas and a shift in judieial philosophy could be expected. The case law seemed to indicate a change of direction. The Supreme Court, for example, in 1969 upheld welfare maximum limitations in Dandridge $v$. Williams. ${ }^{122}$ The

120. See notes 17 \& 57 supra.

121. As to the district court's concern for its competence to deal with the issues posed in Boddie, the appellants offered several arguments. The issues were not intractable and the court's powers were not inferior to the legislature's. A comparison of Boddie with the practical problems posed by such cases as Brown v. Board of Edue., 347 U.S. 483 (1954), Gideon v. Wainwright, 372 U.S. 335 (1963) and Baker v. Carr. 369 U.S. 186 (1962) estahlished that Boddie was readily within judicial competence. Matters relating to court costs and divorce could also be the subject of legislation, but this is true of many matters, such as reapportionment and criminal procedure which courts routinely entertain.

122. 397 U.S. 471 (1970). The judicial retrenchment evidenced by Dandridge has appeared 
decision could easily have gone the other way, resting upon Shapiro $v$. Thompson, ${ }^{123}$ a case having direct relevance for Boddie. The language used in the majority opinion was particularly troublesome, for it seemed to reject the notion of Shapiro that the condition of the poor posed peculiar problems under the equal protection clause. Instead, Justice Stewart, in dealing with these problems, relied upon old decisions applying a minimal equal protection test in the business, economic regulation area. As Justice Brennan pointed out in dissent, matters going to the very core of survival are of a different quality from those involved in economic enterprises. ${ }^{124}$

The main thrust on reargument was to emphasize due process and the narrowness of the possible holding in Boddie on that ground. The due process contention was greatly strengthened by Sniadach $v$. Family Finance Corporation ${ }^{125}$ and Goldberg v. Kelly. ${ }^{126}$ Both decisions had been rendered subsequent to the first argument; both

as well in other cases. While Boddie was pending decision, the Supreme Court, on January 12, 1971, decided Wyman v. James, 400 U.S. 309 (1971). The majority held a welfare recipient's benefits may be terminated for refusing a home visit, although no cause bad been shown for the visit. The trial court, in James v. Goldberg, 303 F. Supp. 935 (S.D.N.Y. 1969), had held that such a visit constituted a search, and conditioning benefits on a waiver of fourth amendment rigbts was unconstitutional. Justice Blackmun, writing for the majority, found that the social worker's purpose was rehabilitative. Hence, the visit either was not a search or, if a search, it was reasonable. The opinion showed a curious innocence concerning past welfare practices. $C f$. Parrish v. Civil Serv. Comm'n, 66 Cal. 2d 260, 425 P.2d 223, 57 Cal, Rptr. 623 (1967). It also reflected a strangely antiquated willingness to equate public assistance with private charity. E.g., 400 U.S. at 319. Most significant, there was little emphasis on the crucial nature of welfare, going to the very capacity of the poor to survive. This emphasis was found, by contrast, in the dissenting opinions of Justices Douglas, Marshall and Brennan, as well as in the majority opinions in Goldberg v. Kelly, 397 U.S. 337 (1970); Sniadach v. Family Fin. Corp., 395 U.S. 337 (1969); Shapiro v. Thompson, 394 U.S. 618 (1969). The court in Wyman was clearly reflecting a fundamental shift in perspective from those carlier cases.

123. 394 U.S. 618 (1969). A decision invalidating maximum grant limitations could have emphasized the impact upon the family, affecting such basic considerations as privacy, marriage and procreation. See note 119 supra. The Court in Shapiro held that a heavy-almost impossible-burden of justification rests on a state which discriminates so as to affect fundamental interests. A similar burden is incurred if the discrimination is based on suspect criteria, such as race. Since the maximum grant limitation in Dandridge related only to AFDC recipients, and since that category of assistance usually has a much higher percentage of Negroes than the others (OAA, AB and APTD), a racial factor could also have been found. But see Ward v. Winstead, 314 F. Supp. 1225 (N.D. Miss. 1970) and Stanley v. Brown, 313 F. Supp. 749 (W.D. Va. 1970).

124. The appellants on reargument attempted to adjust to Dandridge by distinguishing it on the ground that Boddie involved first amendment interests, whereas only equal protection had been involved in Dandridge.

125. 395 U.S. 337 (1969).

126. 397 U.S. 254 (1970). 
were due process cases; both had broad impact on state procedures; both emphasized the compelling needs of the poor; and both were decided in favor of the poor. Goldberg required prior hearings in welfare termination cases, while in Sniadach the Court held that prejudgment wage garnishments were improper without an evidentiary hearing. Thus, the emphasis in both was on the due process requirement for a hearing.

The appellants argued that, as in Goldberg and Sniadach, they only sought a hearing. But appellants' need was more basic, for while the litigants in Goldberg and Sniadach would have gotten a later hearing, in Boddie the appellants had been denied all right to a hearing. Indeed, they could not even petition for a hearing. The impact upon them was analogized to the loss of welfare and wages, for inability to obtain a divorce indeed has severe economic consequences. The nature of the interests involved - the use of wages, the privilege of welfare, the statutory entitlement to divorce-clearly, upon comparison, also favored the appellants in Boddie, for the Supreme Court had several times found marriage and procreation to be constitutionally fundamental.

Thus a position which began by building upon equal protection precedent shifted emphatically to a narrower, but more firmly based due process approach. As mentioned at the outset, test case litigation sometimes requires a sea captain's sense of the sea. And so appellants emphasized that a due process holding, resting on the first amendment guarantee of the right to petition for redress of grievances, would involve only court fees. Unlike an equal protection argument, there need be no implications for other procedural expenses or, indeed, for non-court state fees.

One of the dangers of protracted poverty litigation is mootness. This has been said before, but it bears repeating here. The appellees in Boddie introduced a mootness claim, without warning in the briefs or otherwise, for the first time at reargument. ${ }^{127}$ Their position was not entirely clear, but they seemed to be saying that appellants were no longer poor; or, if they were, there were now federal and state programs to pay court costs for poor litigants.

Appellants sought two weeks to submit affidavits, which were submitted on behalf of themselves and from legal services programs around the country. The best source of information, however, the 
Office of Economic Opportunity, never submitted an affidavit. At a time of acute political travail, the staff hesitated ${ }^{128}$ to document what everyone knew: OEO did not-could not-fund court costs for poverty litigation and thousands of poor persons were thus left without redress. On the Friday following reargument, a promise of an affidavit was finally made. The next day, the promisor and the Director of Legal Services were both fired. No affidavit ever came from $O{ }^{129}$ and the crucial void thus left was finally filled by a memorandum submitted by Solicitor General Erwin Griswold.

Appellants' personal affidavits ${ }^{130}$ indicated the subsistence level at which they existed. Indeed, these affidavits demonstrated the impossibility of making ends meet at such levels. One appellant, with an income of $\$ 2600$ per year paid $\$ 1200$ for rent; the remainder was for everything else needed to support herself and her child. A second appellant, on an income of $\$ 3250$ annually, supported herself and one child; $\$ 1400$ of that went for rent. A third appellant, with an income of $\$ 4800$, fed six children. The appellants' total assets-furniture, clothing, belongings-ranged from $\$ 200$ to $\$ 400$. In each instance, they estimated their expenses exceeded their income.

The affidavits from agencies around the country demonstrated the universality of the problem facing these appellants. There was simply nowhere to turn for court fees. The Department of Health, Education and Welfare ${ }^{131}$ could not help. The Office of Economic Opportunity, according to the Solicitor General, ${ }^{132}$ could not assume the burden. His memorandum estimated that 267 neighborhood law programs, employing 2,000 lawyers in 900 offices, had handled over 900,000 matters in 1970 . Of these, 60,000 involved domestic relations. Funds were so limited that only one percent of a program's budget could be allocated to meet court costs such as transcripts and appeals; and OEO discouraged using funds for routine filing fees. To meet the

128. During the week following reargument, appellants' counsel placed approximately one dozen phone calls to the Washington Legal Services Office of OEO. The staff was most considerate and concerned about Boddie. They felt keenly, however, the political tension and uncertainty surrounding the agency. See notes 2 \& 25 supra. No criticism of them is intended, for they were perfectly correct in their assessment of the pressures on the agency.

129. After the firing, negotiations continued with those members of the staff who remained and could be contacted. Obviously, they had more pressing concerns than Boddie. Nevertheless, several staff members made strenuous efforts to prepare an affidavit, which was eventually submitted as an amicus curiae memorandum by Solicitor General Erwin Griswold.

130. Record at $\longrightarrow$ Boddie v. Connecticut, 401 U.S. 371 (1971).

131. Id. at

132. Brief for Solicitor General as Amicus Curiae at 401 U.S. 371 (1971). 
needs of litigants across the country, Griswold estimated, would require a twelve-fold increase in the budget allocation for court costs. Even that would serve only the one in ten indigents who need legal services and who go to a poverty law office. The other nine would not be reached.

The experience at the local level supported Griswold's view of the problem. The affidavits from local legal services programs showed a consistent pattern of denial of services to the poor because they were too poor. New Haven Legal Assistance in 1970 alone was unable to initiate divorce actions on behalf of 150 applicants because of the fee requirement. ${ }^{133}$ The Minneapolis program failed to commence about 300 divorce cases a year because of court costs. The figure in Phoenix was estimated to be "hundreds;" in Portland, Oregon, 100 to 200 applicants per month; in Pittsburgh, the estimate was "large numbers;" in St. Louis, "hundreds." Affidavits from twenty-five metropolitan programs were filed with the Court. They all showed the same pattern: the limited funds for litigation were being allocated for transcripts, depositions and appeals. No program could begin to pay filing fees for routine litigation. Thousands of clients were thereby denied access to court. ${ }^{134}$

Accompanying the affidavits was a memorandum on behalf of appellants. Appellants argued that even if some source, somewhere would pay court costs, appellants' constitutional rights could not thus be forfeited. It was the state's obligation to afford access to the courts; it could not shift that obligation to some unrelated private or governmental program. The right to vote, to counsel in criminal cases, to criminal appeals, to hearings prior to welfare termination, to hearings before wage garnishment-none of these had been conditioned on a showing that the person affected could not somehow find the money to survive. Why should such a condition be attached to the right to petition for redress of grievances? ? $^{135}$

\section{The Supreme Court Opinions}

On March 2, 1971 the Supreme Court rendered its opinion in Boddie v. Connecticut. ${ }^{136}$ An eight to one majority held for the appellants, reversing the district court. The lone dissenter was Justice

133. See Record at

134. Id. at

135. Id. at

136. 401 U.S. 371 (1971). 
Black. ${ }^{137}$ The majority opinion was written by Justice Harlan, while two concurring opinions were submitted by Justices Douglas ${ }^{138}$ and Brennan. ${ }^{139}$ Mr. Justice Harlan, noting the undisputed allegations of the complaint, said:

Appellants' welfare income in each instance barely suffices to meet the costs of the daily essentials of life and includes no allotment that could be budgeted for the expense to gain access to the courts in order to obtain a divorce. Also undisputed is Appellants' good faith in seeking a divorce. ${ }^{\text {tho }}$

He then recapitulated the events leading to the federal suit. There was no reference to the factual affidavits submitted following reargument, except in a footnote which said that "[n]othing in these materials [the affidavits] would justify our declining to adjudicate the constitutional question squarely presented by this record."141 Nor was there anywhere in the opinion any reference to the impact upon the poor of denying them access to the courts, particularly the divorce courts. The opinion was a curiously spare, dispassionate constitutional essay, in sharp contrast to the Court's opinions in Shapiro v. Thompson, Goldberg v. Kelly and Sniadach.

Justice Harlan began by saying that ". . . the right to due process reflects a fundamental value in our American Constitutional system." ${ }^{142}$ Central to that value is a system for resolving disputes. For this, we rely on courts to establish a rule of law. "It is upon this premise that this Court has through years of adjudication put flesh upon the due process principle."143

However, Harlan continued, the Court "has seldom been asked to view access to the courts as an element of due process." This is because use of the courts is "not usually the only available, legitimate means of resolving private disputes."144 The courts become so for a person forced into court as a defendant; hence, the Supreme Court's past decisions had been primarily concerned with defendants, assuring them "full access" to the court process.

"Recognition of this theoretical framework," Harlan wrote, "illuminates the precise issue presented in this case." ${ }^{145}$ Unlike

137. Id. at 389.

138. Id. at 383.

139. Id. at 386.

140. Id. at 372-73.

141. Id. at $374 \mathrm{n} .2$. As to the affidavits, see note 140 supra.

142. Id. at 374 .

143. Id. at 375 .

144. Id.

145. Id. at 376 . 
commercial contracts, only court action can dissolve the marital contract. Thus, although the appellants were

"would-be plaintiffs" . . . . Resort to the judicial process by these plaintiffs is no more voluntary in a realistic sense than that of the defendant called upon to defend its interests in court. For both groups this process is not only the paramount dispute-settlement technique, but, in fact, the only available one. ${ }^{11}$

Thus, the past decisions of the Court as to the due process rights of defendants were applicable as guides in Boddie. Those due process decisions establish a right to a hearing, "absent a countervailing state interest of overriding significance."147 The mode and manner of the hearing may vary and default judgments are permissible, but "[w] hat the Constitution does require is an opportunity . . granted at a meaningful time and in a meaningful manner."148 In support of this proposition, Harlan was able to muster an impressive fund of authority, ranging from recent poverty law and criminal cases to corporate cases of both recent and past decades. ${ }^{149}$

It is not enough, Justice Harlan continued, simply to legislate fairly as to the right to a hearing. General legislation fair as to some may be unfair as to others.

The State's obligations . . . are not simply generalized ones, rather, the State owes to each individual that process which, in light of the values of a free society, can be characterized as due. ${ }^{150}$

In this respect, the right to a hearing was of equal dignity with religious freedom, free speech and assembly.

While there might be justifications for fee requirements generally, there was none warranting application to indigents. ${ }^{151}$ Guarding against frivolous litigation did not apply, since there is "no necessary connection between a litigant's assets and the seriousness of his motives in bringing suit;" 152 besides there are better means of guarding against frivolous suits. And, as Justice Harlan noted, financing a court system had been rejected as a justification in Griffin v. Illinois. ${ }^{153}$

146. Id.

147. Id. at 377.

148. Id. at 378, quoting Armstrong v. Manzo, 380 U.S. 545, 552 (1965).

149. 401 U.S. at 377 n.3.

150. Id. at 380 (emphasis added).

151. Id. at 381.

152. Id.

153. 351 U.S. 12 (1956). Significantly, this limited reference to Griffin was the only mention of that seminal case in the entire majority opinion. Justice Harlan studiously avoided reference 
With reference to the expense of service of process, Harlan said that there were alternatives to

a state-paid sheriff if the State is unwilling to assume the cost of official service. This is perforce true of service by publication which is the method of notice least calculated to bring to a potential defendant's attention the pendency of judicial proceedings. ${ }^{1 \mathrm{H}}$

He stated that service at the defendant's last known address "by mail and posted notice" would be as effective as newspaper publication. The implication was that an indigent plaintiff may effect service by mail if a state declines to arrange it for him.

Justice Harlan's concluding remarks emphasized his exclusive reliance upon the due process clause, and the fact that the Court was not going beyond "the case before us, a case where the bona fides of both appellants' indigency and desire for divorce are here beyond dispute." 155 Nor was the Court deciding that access to the courts in other types of litigation could not be "placed beyond the reach of any individual, for, as we have already noted, in the case before us this right is the exclusive precondition to the adjustment of a fundamental human relationship." 156 The opinion ended by saying ". . . we hold only that a State may not . . . pre-empt the right to dissolve this legal relationship without affording all citizens access to the means it has prescribed for doing so." 157

Mr. Justice Douglas would have preferred a ruling based "upon the principles developed in the line of cases marked by Griffin $v$. Illinois." $158 \mathrm{He}$ noted that these cases reached fees, transcripts, counsel and other incidents of court process. The Court's reliance upon due process, in Douglas' view, involved a highly subjective test; other things might be as important as marriage-fishing, licenses, bonds to prevent evictions, housing. The Palko ${ }^{159}$ test as to whether a

to an equal protection analysis of Boddie. This oblique reference to Griffin was as close as he came. The narrowness of his focus is indicated by his failure to cite Shapiro v. Thompson, 394 U.S. 618 (1969), where the Court discussed at great length whether the public purse can be used to justify invidious discrimination. The failure to cite Shapiro drives home the point; Justice Harlan finds due process far more comfortable than equal protection. Significantly, five other Justices joined his opinion without comment. See note 50 supra.

154. 401 U.S. at 382.

155. Id.

156. Id. at 383 .

157. Id.

158. Id.

159. Palko v. Connecticut, 302 U.S. 319 (1937). Justice Douglas did not specifically refer to Palko. It is, however, viewed as the fountainhead of the "shock the conscience" or "fundamental fairness" approach to judicial construction of the due process clause. 
right claimed is "of the very essence of a scheme of ordered liberty [is] highly subjective and dependent on the idiosyncracies of individual judges." 160

Justice Douglas conceded that while the "reach of the Equal Protection Clause is not definable with mathematical precision, rather definite guidelines have been developed:"161 race, alienage, religion, poverty and class or cast. He implied that such discrimination was present in Boddie. "Affluence does not pass muster under the equal protection clause for determining who must remain married and who shall be allowed to separate." 162

Mr. Justice Brennan concurred for much the same reasons as Justice Douglas. However, he endorsed Harlan's due process analysis, with some reservations:

I cannot join the Court's opinion insofar as today's holding is made to depend upon the factor that only the State can grant a divorce and that an indigent would be locked into a marriage if unable to pay the fees required to obtain a divorce. ${ }^{163}$

The reason was that a State has "an ultimate monopoly of all judicial process." 164 Whenever a dispute cannot be settled, the parties must go to court. Such resort "is no more voluntary in a realistic sense than that of the defendant called upon to defend his interests in court." 165 In Brennan's view, a divorce action is like any attempt to invoke the courts to enforce any provision of law; if fees bar the way, the litigant is denied a right to be heard regardless of the interest involved.

Further, Brennan observed, "this case presents a classic problem of equal protection of the laws." 166 True, the right to a hearing is a matter of due process, but Connecticut denied the right invidiously. Such discrimination could be tested under the equal protection clause and the Griffin line of cases.

Where money determines not merely "the kind of trial a man gets," . . . "but whether he gets into court at all, the great principle of equal protection becomes a mockery."167

Mr. Justice Black began his dissent by observing " $[t]$ his is a

160. 401 U.S. at 385 .

161. Id.

162. Id. at 386 .

163. Id. at 387.

164. Id.

165. Id.

166. Id. at 388 .

167. Id. at 389 . 
strange case and strange holding." 168 Historically, marriage and divorce are matters of exclusively state concern. "The Court here holds, however, that the State of Connecticut has so little control over marriages and divorces of its own citizens that it is without power to charge them practically nominal initial court costs when they are without ready money to put up those costs." 169 Justice Black felt neither the equal protection nor the due process clauses supported this result.

Equal protection of the laws was not involved. Griffin was limited by its terms and holding to criminal cases, involving life, liberty and property. The special gravity of criminal proceedings is underscored by the numerous provisions of the Bill of Rights protecting defendants. ${ }^{170}$ Not only are the stakes and the Constitutional trappings less in civil litigation, but also the government is not usually involved as a party. Justice Black placed special emphasis on Cohen $v$. Beneficial Industrial Loan Corporation, ${ }^{171}$ which had upheld a statute requiring some but not all plaintiffs in a stockholders' derivative suit to post a bond. Black argued that Cohen could only be distinguished from Boddie on the basis that Boddie involved marriage. ${ }^{172}$ Such value distinctions are subjective, determined by what at a particular time "shocks" a particular judge's conscience. ${ }^{173}$

\section{ANALYSIS AND IMPLICATIONS}

\section{Comparative Analysis}

The significance of Boddie lies in the majority's holding and its implications, which are discussed later in this article. But some comparative analysis of the opinions in Boddie may sharpen the focus

168. Id.

169. Id. at 390 .

170. $I d$.

171. 337 U.S. 541 (1949).

172. 401 U.S. at 392 . The majority distinguished Cohen by noting that the case did not involve the application of a statute with unconstitutional consequences. By contrast, this statute had been challenged as applied. Id. at 381 n.9. See note 69 supra.

173. Justice Black observed:

With a "shock of the conscience" test of constitutionality, citizens must guess what is the law, guess what a majority of nine judges will believe is fair and reasonable. Such a test willfully throws away the certainty and security that lies in a written constitution, one that does not alter witb a judge's health, belief or his politics. I believe the only way to steer the country towards its great destiny is to follow what our Constitution says, not what judges think it should have said. 401 U.S. at 393. 
of the majority opinion, facilitating the exploration of theoretical implications.

It may be best to begin with Mr. Justice Black. His opinion contains sentiments he has expressed before-a concern that decisions should reflect precise judicial guidelines and textual authority in the Constitution. ${ }^{174}$ One may question whether either is an objective possibility, for the Justices seem to disagree even when they are coping with rights explicitly created by the Constitution. ${ }^{175}$ None of the Justices has ever advocated a carte blanche approach to judicial decision-making. All claim at least to start with the Constitution and to limit precisely their holdings. ${ }^{176}$ Yet rarely do they agree that this is, in fact, being achieved; a comparison of the opinions of Justices Douglas and Harlan in Boddie illustrates this point.

Two other points should be noted with respect to the opinion of Mr. Justice Black. The first is that he nowhere discusses the first amendment guarantee of the right to petition for redress of grievances, a curious omission, since he is a conspicuous advocate of first amendment freedoms. ${ }^{177}$ Second, Mr. Justice Black's reference to the state's inability to charge "practically nominal initial court costs when they [plaintiffs] are without ready money to put up those costs," 178 is fraught with inchoate significance. The assumption apparently is that some costs conditioning fundamental rights, if "nominal," can be tolerated. Yet the Supreme Court has held, at least as to voting, to the contrary. ${ }^{179}$

174. See opinions of Justice Black in Duncan v. Louisiana, 391 U.S. 145, 162 (1968) (concurring); Rochin v. California, 342 U.S. 165, 174 (1952) (concurring); Adamson v. California, 332 U.S. 46, 68 (1947) (dissenting). In each of these cases, Justice Black has developed his "incorporationist" view, that the fourteenth amendment guarantee of due process must be related to the Bill of Rights, not vague notions of fundamental justice.

175. See, e.g., Schmerber v. California, 384 U.S. 757 (1966).

176. An example of the varying views held by the Justices may be found in Duncan v. Louisiana, 391 U.S. 145 (1968).

177. The appellants in Boddie placed heavy reliance on that amendment's guarantees, because Justice Black has previously criticized equal protection and due process arguments on the grounds of vagueness. It could be assumed that Black, having consistently urged the incorporation of the Bill of Rights into the fourteenth amendment due process clause, and having treated the right to petition in other cases, would have given some consideration to appellants' position in Boddie. Justice Black joined in the majority opinion in NAACP v. Button, 371 U.S. 415 (1963); and wrote the majority opinions in United Mine Workers v. Illinois Bar Ass'n, 389 U.S. 217 (1967); Brotherhood of R.R. Trainmen v. Virginia Bar Ass'n, 377 U.S. 1 (1964). These are, of course, the leading decisions on the right to petition for redress of grievances in state courts.

178. 401 U.S. at 390.

179. In Harper v. Virginia Bd. of Elections, 383 U.S. 663 (1966), a $\$ 1.50$ poll tax was held 
The task of distinguishing nominal from burdensome costs is a snare of considerable proportions. What is burdensome may depend upon a person's conditions, his expectations, his scale of values. A court must decide whether to accept the individual's view of his position or attempt objective criteria. But there are none; even the socalled "poverty line" is far from a matter of consensus. ${ }^{180}$

The reference to "ready cash" is equally troublesome. Because the poor in this nation have cash and can obtain credit, few fee barriers are an insuperable burden. ${ }^{181}$ If they lack "ready cash," they can save their money until they have enough, and Justice Black seems to be implying that a state may legitimately require them to do so. This ignores the economic pressures upon the poor, which frustrate conserving income. ${ }^{182}$ And it ignores the public interest in encouraging prompt exercise of rights. Perhaps most important, Black's view could place a burden of delay upon the poor which might prejudice their legal position when compared with that of the affluent. The "ready cash" notion, then, could lead to a denial of equal protection of the laws. 183

No analysis of Justice Black's opinion would be complete without reference to The Indigents Cases. ${ }^{184}$ There the Supreme Court declined to review five cases, ${ }^{185}$ remanded another two ${ }^{186}$ for reconsideration,

to abridge the right to vote. Also, filing fees of $\$ 4.00$ and $\$ 20.00$ were held to violate equal protection guarantees in Smith v. Bennett, 365 U.S. 708 (1961) and Burns v. Ohio, 360 U.S. 252 (1959).

180. See notes $83 \& 84$ supra for a brief discussion of the meaning of indigency. Obviously, a court must at times determine whether a person is indigent. But once that is established, whether a charge is "nominal" or not should be irrelevant-the indigent should be relieved of any obligation of payment. A "sliding scale" of indigency would be administratively unmanageable-an invitation to arbitrariness.

181. Indeed, the ready availability of credit is one of the contributing factors to the oppressive condition of poverty in this country. See D. CaPLovitz, supra note 18, at 94-115.

182. See id.

183. At least to the extent that delay means forfeiting legal rights-it would have been appropriate for the state court in Boddie to have accepted the papers for filing, subject to the fees being paid at a later time. The costs might then have been assessed against the husband once in court, or deferred until after judgment. Following Boddie, Connecticut's Chief Court Administrator in a Memorandum to Superior Court Clerks advised them to seek payment of costs from husbands. See note 206 infra. In any event, delay for collection should not prejudice an indigent's legal rights. See Tate v. Short, 401 U.S. 395 (1971).

184. U.S. (1971).

185. Meltzer v. G. Buck LeCraw \& Co., __ U.S. __ (1971) (penalty if tenant opposes eviction and loses); Beverly v. Scotland Urban Enterprises, U.S. __ (1971) (penalty bond in appeal from eviction judgment); Bourbeau v. Lancaster, U.S. (1971) (appeal 
and noted one ${ }^{187}$ for review; all of these cases dealt in varying degrees with implications of Boddie. Mr. Justice Black dissented, noting that although he had criticized Boddie ". . . if the decision in that case is to continue to be the law, it cannot and should not be restricted to persons seeking a divorce. ${ }^{188}$ Therefore, he would have granted review in all The Indigents Cases or reversed outright. Justice Black's reasoning was based on his conclusion that Boddie

... can safely rest on only one crucial foundation-that the civil courts of the United States and each of the States belong to the people of this country and that no person can be denied access to those courts, either for a trial or an appeal, because he cannot pay a fee, finance a bond, risk a penalty or afford to hire an attorney. ... [1]n my judgment Boddie cannot and should not be limited to either its facts or its language, and I believe there can be no doubt that this country can afford to provide court costs and lawyers to Americans who are now barred by their poverty from resort to the law for resolution of their disputes. ${ }^{189}$

Justice Black criticized the majority's attempt to limit its holding. While judicial relief is the only means of ending marriages, it is equally true that such relief is the only way of effectively and finally resolving any legal relationship or dispute. Property rights and tort damages are, after all, valuable only to the extent that the law enforces them. ${ }^{190}$ The other distinction which the majority emphasized-that divorce is fundamental - was also rejected by Justice Black. In his view, marriage is important but not divorce, and "since Boddie held that the right to divorce was 'fundamental,' I can only conclude that almost every other kind of legally enforceable right is also fundamental to our society." 191 A tort recovery, welfare

costs); In re Garland, __ U.S. ___ (1971) (bankruptcy filing fees); Kaufman v. Carter, _U.S. - (1971) (court-appointed counsel).

186. Sloatman v. Gibbons,

Frederick v. Schwarts, U.S. U.S. (1971) (appeal costs).

(1971) (deferred filing fees in divorces); 187. Lindsay v. Normet, _ U.S. _ (1971) (penalty bond for appeal from eviction judgment).

188. Meltzer v. G. Buck LeCraw \& Co., __U.S. at _ n.1 (1971).

189. UU.S. at

190. Of course, in Boddie judicial action was mandatory. Nevertheless, in Justice Black's view

the Boddie rationale would go far beyond divorce. Citizens generally must resort to courts for adoptions, to probate a will, to obtain a discharge in bankruptcy, for child custody determinations, to clear title to land in rem, to obtain an adjudication of incompetency, to change a name, and for other matters. It would be extremely arbitrary to limit Boddie to these particular kinds of disputes. U.S. at

191. Id. at 
assistance or bankruptcy relief are all, in Black's view, as socially significant as divorce.

Justice Black felt that Boddie also had implications beyond simply relieving the poor of trial fee barriers. Court-appointed counsel ${ }^{192}$ and access to appellate review, free of fees, transcripı costs and bonds, are all embraced by Boddie. The need for court-appointed counsel would be particularly acute in a state-initiated custody proceeding, which in Black's view "by its very nature resembles a criminal prosecution." 193

The opinion of Justice Black in The Indigents Cases puts his Boddie dissent in a confused perspective. In Boddie Black seemed to be rejecting unqualifiedly the validity of the appellants' claim. In The Indigents Cases he appears at some points to be conceding the validity of that claim, while at other points, he is simply accepting it as a fait accompli. In any event, his dissent in The Indigents Cases is the first authoritative evaluation subsequent to Boddie by a critic, and as such it is persuasive evidence that the majority's effort to narrow Boddie's holding was unsuccessful. Justice Black thus lends substance to the views expressed in Boddie by Justices Douglas and Brennan.

The opinions of Justices Douglas and Brennan are correct in concluding that Boddie is susceptible of an equal protection analysis. Indeed, Harlan does not challenge this in his opinion. Brennan seems equally correct in conceding the propriety of a due process approach. Justice Douglas does not really disagree; he simply echoes Black's theme that a due process analysis has unclear implications in contrast to those of equal protection.

Here, Justice Douglas would seem to be on uncertain ground. He ignores the obvious point that Harlan has attempted to limit the majority holding to cases involving court process. While this may be feasible with due process, it is not with equal protection, as Douglas implicitly concedes. ${ }^{194}$ Further, the Court's opinion does not, as contended by Douglas, turn upon the basic importance of marriage as

192. . . . there cannot be meaningful access to the judicial process until every serious litigant is represented by competent counsel. Of course, not every litigant would be entitled to appointed counsel no matter how frivolous his claims might be but the fundamental importance of legal representation in our system of adversary justice is beyond dispute. Since Boddie held that there must be meaningful access to civil courts in divorce cases, I can only conclude that Boddie necessitates the appointment of counsel for indigents in such cases. Id. at ___ [citations omitted].

193. Id. at

194. 401 U.S. at 386. 
a due process-protected interest. Rather, Harlan seems to be saying that the significance of marriage is that the state allows no means of dissolution except by court process. ${ }^{195}$ This would be applicable to any right, no matter how frivolous, if the state monopolized the means of resolving disputes. If, as Douglas contends, Harlan emphasizes the fundamental importance of marriage and divorce, it is only to balance against whatever interest the state may have in a fee system, ${ }^{196}$ not to elevate it above other interests a citizen may have.

Finally, whatever vices due process may have, Mr. Justice Douglas is hardly convincing in arguing the greater precision of equal protection. He refers to such criteria as race, poverty, alienage and class. ${ }^{197}$ But these only define some of the "suspect criteria" offending the equal protection clause. ${ }^{198}$ That clause may be violated by other lines of classification or, indeed, by merely irrational classifications. Further, these criteria do not define the interests cognizable under the equal protection clause. Therefore, equal protection offers no more certain guidelines as to the status of fishing (to use Douglas' example) ${ }^{199}$ than reliance on the due process clause. Mr. Justice Douglas is doubtless right in saying that he cannot "see the length of the road" under Harlan's approach, but he would seem wrong in assuming that the road is clearer with equal protection.

Mr. Justice Brennan, as noted, seems willing to concede more than Justice Douglas to the majority's due process approach. But Justice Brennan rejects Harlan's attempt to limit Boddie by dependence "upon the factor that only the State can grant a divorce." $200 \mathrm{He}$ contends that this is not unique, since the state has a monopoly on all judicial redress. Generally speaking, parties are not allowed to settle disputes by force or violence; that is the prerogative of the state. Indeed, in many areas, even non-violent self-help has been declared against public policy. ${ }^{201}$ While citizens may renegotiate agreements or settle disputes privately, their arsenal of weapons is sharply curtailed. The most potent forms of recourse-force and violence-have been appropriated to the state. Therefore, plaintiffs go to court no more

195. Id. at 376. In each instance, Justice Harlan's reference to the basic nature of marriage is en passant to his basic point: these plaintiffs could get relief only in court.

196. Id.

197. Id. at 385 .

198. See Shapiro v. Thompson, 394 U.S. 618, 631-33 (1969).

199. 401 U.S. at 385.

200. Id. at 387.

201. See note 13 supra. 
willingly than defendants. ${ }^{202}$ The truth of this is self-evident-no one welcomes or bargains for a law suit. Brennan, by this analysis, would seem to have scored a telling point on Justice Harlan's majority opinion. If so, the decision has substantially broader implications than Harlan contemplated.

In the majority opinion, Mr. Justice Harlan totally avoided an equal protection analysis, limiting the majority opinion to a due process right to a hearing focus. Unsuccessfully perhaps, he attempted further to limit Boddie to cases in which the litigant has no alternative to court action. Despite all this, the opinion could have been narrower. The majority's emphasis on access to the judicial process and to a full hearing carried them beyond saying merely that the appellants had a right to get into court. Had Justice Harlan based his opinion on the explicit first amendment right to petition for redress instead of the broad due process analysis, the majority might not have reached the issue of service of process. ${ }^{203}$

The majority opinion imposed a surprisingly demanding burden on the state in order to justify the statute. Justice Harlan, by treating the right to a hearing as being of equal dignity with religious freedom and the right to assembly, required the state to justify the fee statute by demonstrating a compelling state interest. ${ }^{204}$ And overbreadth was a critical flaw in the fee statute, ${ }^{205}$ even assuming the presence of a

202. 401 U.S.at 387.

203. It is not surprising, of course, in view of his past opinions, that Justice Harlan would avoid reliance upon specific provisions of the first amendment, preferring instead a broader due process analysis based upon notions of fundamental values in our constitutional system. For the context and some of the content of Justice Harlan's views on due process see Sniadach v. Family Fin. Corp., 395 U.S. 337, 342 (1969) (concurring opinion); Shapiro v. Thompson, 394 U.S. 618, 655 (1969) (dissenting opinion); note 174 supra.

204. See, e.g., Stanley v. Georgia, 394 U.S. 557 (1969); Tinker v. Des Moines School Dist., 393 U.S. 503 (1969); Brown v. Louisiana, 383 U.S. 131 (1966); Sherbert v. Verner, 374 U.S. 398 (1963); Dennis v. United States, 341 U.S. 494 (1951). In contrast, traditionally, due process is satisfied by a minimal showing of rationality for legislation, at least since the death of "substantive" due process. See the following business regulations cases: Railway Express Agency v. New York, 336 U.S. 106 (1949); Olsen v. Nebraska, 313 U.S. 236 (1941); Nebbia v. New York, 29 I U.S. 502 (1934); Lochner v. New York, 198 U.S. 45 (1905). In the area of social welfare legislation, a similarly permissive approach obtains. See Williams v. Dandridge, 397 U.S. 471 (1970); Flemming v. Nestor, 363 U.S. 603 (1960).

205. 401 U.S. at 381 . Overbreadth is customarily not a fatal vice except in first amendment cases. Compare cases at note 204 supra, and Williams v. Dandridge, 397 U.S. 471 (1970) with Cox v. Louisiana, 379 U.S. 536 (1965). Justice Harlan thus imported a first amendment approach into Boddie, although he did not explicitly rely on that amendment. He did not, however, void the entire statute for overbreadth, as is often done in first amendment cases. 
compelling state interest. Due process in cases not involving the first amendment is usually satisfied by a valid state interest.

The majority's opinion, like Justice Black's has some troublesome inchoate assumptions. Justice Harlan repeatedly emphasized that appellants' bona fides in seeking divorces had been admitted. This may have simply been a product of the majority's wish to underscore the narrowness of the issues before them. Unfortunately, this language may be viewed as requiring a trial court to investigate bona fides in an in forma pauperis application. ${ }^{206}$ As a matter of equal protection, states may not make such inquiry with criminal appeals by indigents unless it also does so with affluent litigants ${ }^{207}$ and there is no reason to believe that Harlan's due process approach of balancing interests requires a different result. At a minimum, this would delay divorces, requiring two hearings instead of one and exposing divorce litigants to additional embarrassment in open court.

Justice Harlan's emphasis on bona fides leaves open many questions. If a hearing on good faith must be held, where shall the burden of proof lie? Shall the standard require only a prima facie showing or proof by a preponderance of the evidence? May the spouse or the Welfare Department appear in opposition? What is the issue? Presumably, the trial court might require evidence as to whether technical grounds exist; whether the home-as a sociological unit-will benefit from divorce; or whether the plaintiff by her conduct "deserves" a divorce in some moralistic sense. By leaving

206. In point of fact, following Boddie the Administrative Office of the Connecticut courts took this position. Memorandum of March 18, 1971 from Justice Cotter of the Connecticut Supreme Court to Clerks of the Superior Court. Cotter, Chief Court Administrator, advised the Clerks that:

The court should specifically find the existence or nonexistence of the bona fides of the applicant's indigency and the fact whether or not the "desire for a divorce [is] beyond dispute." The finding should, if the court so finds, specify the fees, costs and expenses to be waived in favor of the applicont and in the event the court finds that the defendant is able "to pay either the court fees required by statute or the cost incurred for the service of process" it should consider incorporating in its order a method of recourse to the defendant for payment.

The phrase "desire for divorce" is hardly clear, but presumably Justice Cotter intends some inquiry into whether grounds in fact exist.

207. See Draper v. Washington, 372 U.S. 487 (1963); Douglas v. California, 372 U.S. 353 (1963); Coppedge v. United States, 369 U.S. 438 (1962); Eskridge v. Washington, 357 U.S. 214 (1958); Ellis v. United States, 356 U.S. 674 (1958). The principle to be distilled from these cases is that a state may not discriminate in its court processes against the poor by conditioning access upon the "merit" of the claim unless there is a similar condition imposed upon the affluent. 
such questions unanswered, Justice Harlan has left ample opportunity for a hostile trial court to defeat the relief granted in Boddie. ${ }^{208}$

A small point, but perhaps one worth noting, is Justice Harlan's casual treatment of service of process. If the state declines now to arrange service, a litigant may proceed through the mails and by posting a notice. Yet this may fail to give actual notice when actual notice is possible, for example, when the plaintiff knows where the defendant can be temporarily located or learns of an intermediary through whom the notice might be transmitted. The defendant could conceivably claim a denial of due process if not actually notified. Thus, the plaintiff is subject to a disadvantage in comparison with a wealthy litigant, who could have retained a sheriff to effect personal service. The majority opinion, by permitting the state to refuse to effect service, may thereby disadvantage poor plaintiffs and those whom they sue. ${ }^{209}$

One significant aspect of Justice Harlan's opinion is the standard of indigency employed. The majority opinion notes that "appellants' welfare income in each instance barely suffices to meet the costs of the daily essentials of life and includes no allotment that could be budgeted for the expense to gain access to the courts in order to obtain a divorce."210 Those expenses average approximately sixty dollars. In contrast to Justice Black's approach, this in effect is an objective standard of poverty. ${ }^{211}$ Significantly, the Court to some degree is entrusting the standard to a state agency which, in dealing with welfare matters, has presumably acquired some expertise. This is not to say that non-recipients of welfare are affluent; it is only to suggest that after Boddie, those receiving welfare or living at welfare levels are indigent for in forma pauperis purposes.

Finally, it may be useful to note the curiously abstract, conceptual nature of Justice Harlan's opinion. It is, as usual, tightly written and reasoned. But it represents a sharp contrast to the passionate concern for the plight of the poor reflected in Goldberg $v$. Kelly and Sniadach, both of which were due process cases. Nor does it reflect Justice

208. As to the hostility toward litigation for the poor, see notes $2,18 \& 45$ supra. As to the present reaction of Connecticut's court personnel, see note 206 supra and note 221 infra.

209. The State of Connecticut, following Boddie, made provision for service to be effected by sheriffs, who were to be compensated by the state. Memorandum of Justice Cotter, supra note 206. The Memorandum said nothing as to service by publication.

210. 401 U.S. at 373.

211. See notes 83 \& 84 supra. 
Brennan's concern in Dandridge v. Williams that, in constitutional contemplation, the needs of the poor carry a grave imperative.

Implications for Aspects of Court Process Other Than Fees and Service

Boddie has achieved at least two things: court fees can no longer be demanded of indigents in divorce cases, and courts must arrange service of process or publication of appropriate notice; if they fail to do so, the plaintiff may proceed by mailing notice to the defendant's last address or by posting a notice in an appropriate place.

Yet the major expense of divorce litigation is the hiring of counsel. In a typical uncontested divorce case, the bar association minimum standards usually set the fee at roughly three hundred dollars. This is obviously well beyond the means of most poor people; certainly of welfare recipients. For a client who retains an attorney from a poverty law program, of course, fees are no problem; however, it has been estimated that nine out of ten poor people are not reached by such programs. ${ }^{212}$

The only present alternative for those who cannot benefit from public legal services is to represent themselves. In practice this is hardly feasible. At present, few court clerk's offices can provide appropriate forms. Nor can they assume the burden of advising plaintiffs as to how to fill out the forms or serve them. Few laymen understand the complexities of court calendars, appearance dates, hearing schedules and trial techniques. It is common knowledge among lawyers that uncontested divorces are simple matters, involving little time or talent. But for laymen, they may be an impossible maze.

Then, too, many aspects of divorces are contested. Even in uncontested proceedings, the parties may still disagree as to alimony, support and custody. Simple matters such as rights and hours of visitation often prove to be sources of contention where spouses are vindictive or hostile. Obviously, in a contested hearing, particularly if one side has counsel, a layman has little likelihood of protecting his interests.

All of this suggests the necessity for appointed counsel in divorce cases. The opinions in Boddie sedulously ignore the subject. Even Justice Black does not mention it, although he raised the issue at both

212. Brief for Solicitor General, supra note 132, at 
the argument and the reargument. ${ }^{213}$ On both occasions, appellants argued that while counsel is constitutionally required by the sixth amendment in criminal cases, a holding in Boddie based upon the first amendment right to petition for redress of grievances could be sufficiently narrow to avoid the issue of appointment of civil counsel. However, the majority in Boddie did not so limit their holding.

The very breadth of Justice Harlan's due process approach, emphasizing the central place of peaceful dispute-resolution in our society, admits the necessity of a place for counsel. The Court concerned itself with the right to a hearing and a hearing is of little value without counsel, whether in a criminal ${ }^{214}$ or a welfare setting. ${ }^{215}$ If counsel can be required in such "civil" settings as juvenile courts, parole revocations, appeals and commitments, why not divorces?216 The right to counsel argument is assisted by Justice Harlan's view of the appellants in Boddie as being, in reality, cast in the role of the defendants. When the state places a person in such a position, it should incur the obligation of providing him with counsel. ${ }^{217}$

213. 39 U.S.L.W. 3221 (U.S. Nov. 24, 1970). See notes 184-93 supra and accompanying text. A related problem involves the requirements in some states that counsel be provided for an absent defendant in a divorce proceeding. It would seem that the state must bear this expense, not the plaintiff, since it is a state-imposed barrier to court access, like the court fees in Boddie.

214. See Gideon v. Wainwright, 372 U.S. 335 (1963); Powell v. Alabama, 287 U.S. 45 (1932).

215. See Goldberg v. Kelly, 397 U.S. 254 (1970), as to the vital role of the right to counsel at a welfare termination hearing. The Court in Goldberg, however, carefully eschewed saying that there was a right to appointed counsel, perhaps because HEW had previously adopted a regulation requiring appointment of counsel. That regulation never became effective. See also Jenswold v. St. Louis County Welfare Bd., 247 Minn. 60,76 N.W.2d 639 (1956), holding that a welfare department may compensate a recipient for attorney's fees in a custody case under a statute authorizing financial assistance for the "necessities of life."

216. A full discussion of the case law on the extent of the right to appointed counsel in civil cases is beyond the scope of this article. The arguments in support of the right are fully developed in the following comprehensive, but dated, articles: Note, The Right to Counsel in Civil Litigation, 66 Colum. L. Rev. 1322 (1966); Note, The Indigent's Right to Counsel in Civil Cases, 76 Yale L.J. 545 (1967).

217. It remains true, of course, that the Court did not reach this issue or even discuss it. Optimism as to effecting a favorable decision on the issue of appointed counsel must remain guarded. Had the Court wanted to presage a later holding requiring appointed counsel, it could easily have done so, as it has in the past on other issues in such cases as Kent v. United States, 383 U.S. 541, 555-56 (1966) (constitutional guarantees to adults are also applicable to juvenile proceedings) and In re Gault, 387 U.S. I, 58 (1967) (constitutional right to appellate review from juvenile procedings). On the other hand, the Court could have disposed of the issue negatively in Boddie. Its failure to do so leaves a basis for optimism. Further, at least one Justice has now read Boddie as emphiatically requiring counsel. Meltzer v. G. Buck LeCraw \& $C_{0}$., U.S. (1971) (Black, J., dissenting). 
A somewhat related issue is that involving experts or investigators. A divorce litigant may need a psychiatrist or social worker to testify as to competency for custody purposes. Investigators may be needed for similar purposes, or to obtain evidence for a contested hearing. But because such occasions are rare the arguments concerning appointed counsel would seem to apply with diminished force here; although, cases may arise where such relief might be indispensable. ${ }^{218}$

Boddie lends strong support, however, to the prospect of requiring state provision of transcripts. These become particularly relevant in custody or support matters which may be the subject of several hearings over a period of years. Transcripts may be indispensable to the ability to confront witnesses. ${ }^{219}$ Moreover, transcripts are prerequisites for appeals, whether from rulings of divorce commissioners to the trial court for a trial de novo or from that court to an appellate level.

The requirement of transcripts is implicit in the idea of hearings. While a fair hearing is possible without one, when a transcript could be produced and is important it would seem due process would require the state to provide one to indigent litigants. Unlike appointed counsel, this would not require taxing the capability of existing resources to create new services. The decision of the Supreme Court in In re Gault establishes that at least one Justice, Mr. Justice Harlan, is persuaded of the importance of transcripts. ${ }^{220}$

\section{Other Areas of the Law: Implications for Civil Proceedings Other Than Divorces}

Boddie involved divorces. As to these, court fees and service of process can no longer be required of indigents. Whether they can be required in other forms of litigation was not raised before or decided by the Court. There is some reason, however, to suggest the Court would order waiver of court expenses in certain other forms of litigation.

The most obvious instance would involve cases where the state requires a person to go into court for relief. This was a crucial factor

218. Authorities in related areas of the law, such as criminal cases, are of some support here. See, e.g., Note, Right to Aid in Addition to Counsel for Indigent Criminal Defendants, 47 MiNN. L. REv. 1054 (1963).

219. Cf. Goldberg v. Kelly, 397 U.S. 254 (1970); Pointer v. Texas, 380 U.S. 400 (1965). And see the opinion of Justice Black in Meltzer v. G. Buck LeCraw \& Co., U.S. U. (1971).

220. 387 U.S. 1, 72 (1967) (Harlan, J., concurring in part, dissenting in part). Griffin v. lllinois, 35 I U.S. 12 (1956), of course, involved transcripts. 
for the majority in Boddie and is present in other types of domestic relations litigation, such as legal separation, annullment, child custody, adoption and non-support actions. ${ }^{221}$ Basically, these are matters of state-determined personal status. A similar proceeding, although not involving the same vital interests, would be change-ofname suits. All of these intimately involve the individual as a statedefined entity. Another person may also be affected-a husband, child or parent-yet the object of the suit is to alter a thing, a res, over which the state has taken primary jurisdiction or has asserted a supervening interest. The individual is thereby attorned to the state and can seek relief only from the state. Suits involving such interests presumably, like the divorces in Boddie, could be brought by an indigent without payment of court costs.

In a similar posture are suits against the state. Where the state takes action against the poor it may appear to have the posture of a private litigant, as in suits to compel welfare benefits or effect entrance into public housing or to enjoin an urban renewal project. The state, in such suits, would be sued like any other wrongdoer. Unlike Boddie, the state would not have required the suit to be brought, and the disputing parties would have the option of settling their dispute out of court, which could not be done with a divorce. Thus, Mr. Justice Harlan's critical distinction might come into play.

Yet Justice Brennan's comments must be considered at this point. No plaintiff ever truly comes into court willingly, whether for a divorce or for welfare benefits. For Justice Brennan, the significant point in Boddie was not state monopolization of divorces but state monopolizaton of the right to use force or violence to effect resolution of disputes. This point of view must have weight, if anywhere, in cases alleging state misconduct. It would simply be unconscionable if a state could engage in wrongdoing and then bar an indigent victim from its courts. ${ }^{222}$ Particularly is this true in view of the vital interests which are often at stake in the relationship between the poor and the

221. The Memorandum of Justice Cotter, supra note 206, indicates in an attached opinion by Justice House that Connecticut intends to wajve costs only as to divorces, not, for example, for legal separations. As noted earlier, Justice Black reads Boddie much more broadly. See notes 184-93 supra and accompanying text.

222. The injured party might still pursue a remedy in the federal courts, as was done in Boddie. See note 58 supra. Absent a constitutional or federal statutory claim, however, no such suit could be brought. See opinion of Justice Black in Meltzer v. G. Buck LeCraw \& Co., _U.S. 
state. Therefore, Justice Harlan's emphasis on state monopolization of divorce should not preclude waiving costs in litigation where the state is the alleged wrongdoer.

The final area of litigation where Boddie might apply would involve suits between private individuals, where the state neither has asserted an interest in the subject or is a party. It is here that the narrowness of Justice Harlan's approach most forcefully appears. Private parties can settle their own disputes; there are alternatives to court action. Yet a poor person faced by an intransigent opponent may have no realistic opportunity to bargain. Where a creditor has wrongfully repossessed furniture, or a landlord has wrongfully locked out his tenant, the economics of the situation preclude bargaining. ${ }^{223}$ This is all too often the position of indigents. If they cannot gain access to the courts, the state has in effect favored the intransigent wrongdoer.

So viewed, Justice Harlan's limitation on Boddie cannot last. It may have been a legitimate recognition of the limited facts in Boddie, but it will not bear application elsewhere. Indeed, Harlan's own reasoning supports this. The plaintiffs, he said, in Boddie were in reality in the position of defendants since they were forced into court. Yet this is equally true of all plaintiffs. They are all complaining about a previous wrong; they have all been imposed upon; vis-a-vis the wrong and the wrongdoer, they are defendants, seeking to enforce a counterclaim. Sniadach v. Family Finance Corporation ${ }^{224}$ was of this order. While the appellant was a defendant whose wages had been garnished, he could as easily have been a plaintiff, seeking to remove a wage attachment. Similar comments apply with respect to Goldberg $v$. Kelly. ${ }^{225}$ The roles of plaintiff and defendant are often functionally indistinguishable.

Justice Harlan's due process analysis, then, leads to waiver of court fees in all forms of litigation. There is some irony in this, for the majority's approach was seemingly calculated to avoid the breadth of an equal protection analysis. The latter approach, however, might have limited waiver of court fees to cases involving constitutionally cognizable interests, such as marriage, race or first amendment interests. No such limitations are possible under the majority's due process approach, at least as structured by Justice Harlan.

223. See notes $2,15 \& 18$ supra.

224. 395 U.S. 337 (1969).

225. 397 U.S. 254 (1970). 


\section{Other Areas of the Law: Implications for Non-Court Fees}

The majority in Boddie was concerned with the right to a hearing and the extent to which that right might properly be conditioned upon financial considerations. Justice Harlan thus avoided dealing with the problem of non-court fees. It quite clearly would have been raised by an equal protection resolution of Boddie, as suggested by Justice Douglas. The most that can be said after Boddie is that fundamental rights cannot be conditioned upon a person's ability to pay. This was clearly true of the right to vote prior to Boddie. It is now equally true of the right to a hearing and to access to the courts.

Other matters remain unclear. During oral argument counsel for appellants suggested that license fees as to fundamental interests should be waived for indigents. Marriage would so qualify, as might licenses affecting privacy. Support here might be found in Shapiro $v$. Thompson. An argument could also be made that fees affecting the ability of the poor to survive economically should also be waived: such as the fees required for driving licenses, or the bond requirements under financial responsibility laws. ${ }^{226}$ Some support for this can be derived from Justice Marshall's dissent in Dandridge $v$. Williams. ${ }^{227}$

But such matters are beyond the ambit of the majority's opinion in Boddie. Contrary to Justice Douglas' view, the majority holding did not turn upon the particular nature of certain human values or activities as fundamental. Boddie does not elevate marriage above fishing, for example, as a matter of constitutional import, although that comparison might be dictated by other cases. Instead, Justice Harlan simply said that the due process right to a hearing is fundamental. This may have broad implications as to what kinds of court expenses or services must be provided indigents; it may have implications for types of litigation other than divorces; but such a holding adds little to pre-existing case law as to the right of an indigent to avoid paying non-litigation-related state fees.

226. See Bell v. Burson, __ U.S. __ (1971); Roberts v. Burson, 322 F. Supp. 380 (N.D. Ga. 1969) (relief denied); Llamas v. Department of Transp., 320 F. Supp. 1041 (E.D. Wis. 1969) (complaint dismissed); Perez v. Tynan, 307 F. Supp. 1235 (D. Conn. 1969) (complaint dismissed). The argument based on the need of the poor to survive may sweep too broadly, interpreting equal protection to impose an affirmative duty of support on states, see note 28 supra, which the Supreme Court has long avoided. See, e.g., Shapiro v. Thompson, 394 U.S. 618 (1969); Edwards v. California, 314 U.S. 160 (1941) (where the Court emphasized the right of states to discontinue public assistance).

227. 397 U.S. at 552. 


\section{CONCLUSION: THE AFTERMATH OF VICTORY}

By the time of the reargument in Boddie, only three of the nine plaintiffs remained. One of those, Gladys Boddie, came angrily into the neighborhood law office one week before the decision and paid her money for court costs. Her case was filed the day of the decision. Any general who loses seven-ninths of his troops in battle has in a significant way won a Pyrrhic victory for his clients.

Yet Boddie is a substantial victory for the poor. The thousands who.were annually being refused hearings in divorce cases prior to Boddie now have clear access and many who previously did not even apply for legal assistance may now do so. The benefits in other areas of litigation are less clear, yet they also seem real. ${ }^{228}$ The result, then, was worth the investment.

That investment was substantial. Three extensive briefs and a memorandum were filed in the Supreme Court; similarly extensive papers were required to bring the case through the district court to the Supreme Court. The investment in typing, reproduction and travel alone ran well above a thousand dollars. Nearly two years of counsel's time were uncompensated, but a fair estimate of the expense of legal services-if compensation by a poverty law program had been involved - would have been several thousand dollars. Demands of this scope tax severely the limited resources of a poverty law program, which must carefully weigh the probability and value of success against the likelihood that all will come to naught.

In this instance, most factors augured well. The clients and defendants were stable and the fact situations were relatively fixed. More clients were available for substitution if necessary. The record could be made simply and the significant issue isolated and preserved. The basic law was strong and the extension to be obtained was within reason. All the criteria for successful law reform, discussed above, were evaluated at the outset and constantly re-evaluated. The case held together, with a substantial input of serendipity at the end.

228. The benefits of Boddie in litigation other than divorce, and for procedural hurdles other than trial-level filing fees, are unclear after the Supreme Court's action in The Indigents Cases, U.S. (1971); decided after Boddie. See notes 185-94 supra and accompanying text.

The Supreme Court denied review in five cases raising issues collateral to Boddie. But in two similar cases, the Court remanded for reconsideration. And it noted jurisdiction of one case dealing with appeal bonds. To the extent any inference is possible from this confusing activity, it would seem that the Court is willing to consider extending Boddie, but intends to do so with much deliberation and only prudent speed. 
Still, like Jarndyce v. Jarndyce, Boddie is not yet over. As this is being written, applications to proceed in forma pauperis in the Connecticut courts have been filed and are pending. The state courts are taking an unfortunately narrow view of what Boddie held. The battle is not yet won. 229

And the Connecticut legislature is considering a bill to double court fees....

229. On June 30, 1971 the United States District Court for the district of Connecticut entered judgment following remand by the Supreme Court in Boddie. It ordered defendants to grant the relief sought. In a two paragraph per curiam opinion the court said:

The so called bona fide hearing appears to have been eliminated from the proposed [Conn.] rules, and properly so, since dismissal of applications as frivolous, surely within the court's power if applied equally in fee paid as well as indigent cases, might well amount to a denial of equal protection if applied only in the cases of indigents. Boddie $v$. Connecticut, __ F. Supp. ___ (Docket number civil no. 12513, D. Conn. 197I). 
$$
\text { , }
$$ 